\title{
REVIEW
}

\section{The potential importance of grazing-resistant bacteria in planktonic systems}

\author{
Klaus Jürgens ${ }^{1}$, Hans Güde ${ }^{2}$ \\ ${ }^{1}$ Max-Planck-Institut für Limnologie, PO Box 165, D-24302 Plön, Germany \\ ${ }^{2}$ Institut für Seenforschung, D-88085 Langenargen, Germany
}

\begin{abstract}
The paradigm of the 'microbial loop' has became increasingly important for understanding the structure and function of aquatic ecosystems. Most of the microbial loop studies have focused on energy flow and nutrient cycling. Much less is known, however, about the importance of grazing as a force shaping the structure and community composition of planktonic bacteria. Theoretical considerations of predator-prey interactions suggest that predator evasion mechanisms should have evolved for bacteria in the same way as in other predator-prey systems (e.g. zooplankton-phytoplankton). Consistent with this hypothesis, field data show that bacteria are often the most stable component of planktonic communities. Refuges from grazing are one of the possible mechanisms buffering bacterioplankton against strong seasonal fluctuations in abundance. Substantial direct and indirect evidence exists for the occurrence of grazing-resistant bacteria (GRB) in both marine and freshwater habitats. We summarize the potential mechanisms for grazing resistance, including morphological, chemical and behavioral defenses as well as growth in spatial refuges. Cell size appears to be an important factor influencing susceptibility to grazing, with a refuge at the lower and upper ends of the bacterial size range. Thus, a relative grazing resistance can be assumed for the large number of ultramicrobacteria as well as for morphologically complex growth forms such as filaments and aggregates. Besides morphological features, resistance may be achieved by other mechanisms for which, however, much less information is available. We describe how GRB can be included in conceptual models of the interactions among metazooplankton, bacterivorous protozoans and bacteria. It is suggested that the relative importance of GRB increases with increasing grazing pressure exerted by protozoans, whereas it decreases with increasing top-down control of protozoans by metazooplankton. GRB may reduce the productivity of planktonic systems through decreased trophic transfer efficiencies and reduced regeneration of bacterially bound nutrients.
\end{abstract}

KEY WORDS: Bacteria - Protozoa P Predation · Microbial loop

\section{INTRODUCTION}

Heterotrophic bacteria are an important component of marine and freshwater planktonic systems. Bacterioplankton can consume 30 to $60 \%$ of the primary production via dissolved organic matter (Williams 1981, Azam et al. 1983, Cole et al. 1988) and bacterial biomass often comprises a major fraction of particulate organic carbon, in oligotrophic systems even surpassing phytoplankton biomass (Cho \& Azam 1988, Fuhrman et al. 1989, Simon et al. 1992). As a consequence, the fate of bacterial biomass is central to the under- standing of the carbon flow pathways. Grazing by phagotrophic protists, especially heterotrophic nanoflagellates (HNF), has been identified as the main bacterial loss factor (e.g. Fenchel 1982b, Sherr \& Sherr 1984, Wright \& Coffin 1984, Pace 1988) and can often more or less balance bacterial production.

When thinking about the role and implications of bacterivory in aquatic systems, at least 2 main lines of consideration must be brought into mind:

(1) From a functional point of view, it has been convincingly argued that bacterivory is a major mechanism for the regeneration of nutrients (Azam et al. 
1983. Caron \& Goldman 1990) as well as for transferring energy to higher trophic levels which otherwise would be lost to the food web (Sherr \& Sherr 1988).

(2) From a structural point of view, one can hypothesize that bacterivory should be one of the major forces shaping the genotypic and phenotypic composition of bacterial communities. Considering that bacteria are the oldest form of life on earth, predator-prey relationships should have developed early in the history of bacteria and their consumers. Thus, the main selection forces driving such coevolution, i.e. optimizing predator avoidance by bacteria and the foraging efficiency of bacterivores, must have played an important role in the evolutionary development of both groups.

The functional aspect has clearly dominated among studies dealing with bacterivory in the aquatic world, whereas the evolutionary perspective has gained much less attention. Lack of information concerning the grazing impact on the composition of natural microbial communities is to some degree a result of methodological limitations. Bacteria, as well as the majority of their grazers, have been considered primarily as uniform functional units. The resulting rather simplistic view of the role of bacteria and microbial food webs was sufficient for a first approach to recognize the importance of microorganisms in aquatic ecosystems. The study of the above-mentioned evolutionary aspects in natural bacterial assemblages, however, depends on a more detailed analysis of the community composition.

We are now beginning to resolve the species composition of natural bacterial communities with the help of recently developed molecular methods for bacterial identification (see Pedrós-Alió 1993). It is too early, however, to draw any conclusions with respect to the interactions between bacteria and their predators until we have followed the dynamics of particular species of bacteria in natural populations. Nevertheless, there are already strong indications from theoretical and experimental studies which suggest that grazing pressure by bacterivores may strongly impact the composition of bacterial communities (Güde 1989). In this review we draw attention to the topic of grazing resistance in planktonic bacteria. We feel that this rather neglected issue needs more consideration because it could substantially alter our understanding of the function and structure of microbial food webs. Moreover, because of the overall importance of planktonic microbes, these aspects can contribute also to a more comprehensive view of pelagic ecosystems.

In the present paper we first briefly outline some theoretical considerations which lead toward the concept of grazing-resistant bacteria (GRB). Then we summarize the potential mechanisms of grazing resistance in bacteria which have been suggested by experimental studies. Field observations which support the concept of GRB in planktonic habitats will be described. We focus mainly on field and experimental studies from planktonic ecosystems but refer to other systems, including sewage, soil and sediments, because of the similar underlying mechanisms. Finally we present a conceptual model in which the development of bacterial grazing resistance is integrated with interactions among planktonic metazoans, protozoans, and bacteria, and try to point to the most important consequences of GRB for the role of bacteria in aquatic ecosystems.

\section{THEORETICAL EXPECTATIONS}

Most of the theoretical work on predator-prey relationships is still based on Lotka-Volterra equations or modifications of them. Because the simple original assumptions made in the Lotka-Volterra equations can hardly occur in nature, most of the modifications were designed to better depict the real world by making more realistic assumptions (see review by Kuno 1987). For the present consideration, there are 2 important points to be emphasized as the most relevant results of these theoretical studies:

(1) Without any additional influencing factors, predator-prey systems are inherently unstable. As was verified by many computer simulations there is a high probability of extinction of either predator or prey populations in the absence of stabilizing mechanisms (e.g. Kuno 1987).

(2) Among the stabilizing conditions leading to coexistence of predator and prey, the most efficient one is the existence of a refuge for the prey species (e.g. Murdoch \& Oaten 1975).

Well-documented examples supporting these 2 points come from studies of the interactions between primary producers and herbivores. The different susceptibility of plant species to grazing mortality has long been a main point of interest and it is well known that herbivory can shift the species succession towards a community dominated by grazing-resistant species (Edwards \& Gillman 1987). This was first studied in terrestrial systems but has also been confirmed for planktonic herbivory (e.g. Porter 1977). The resistance of some algal species to zooplankton grazing is a key factor in the phytoplankton succession of lakes (Porter 1977, Sterner 1989). Therefore, 'resource edibility' has been included in models of interactions between phytoplankton and herbivorous zooplankton (Leibold 1989). It improved the prediction of algae and zooplankton abundances compared to other linear food chain models with 1 uniform population per trophic level (Oksanen et al. 1981). Behavioural, morphologi- 
cal and chemical defenses against predation within planktonic habitats are not limited to phytoplankton but are also important for protozoans, rotifers and cladocerans (Sih 1987).

Grazing resistance could be at least as widespread and important in bacterial communities, considering the obviously high genotypic diversity and phenotypic plasticity of bacteria. The development of GRB can occur in 2 different ways: changes in species composition within a community or phenotypic changes within a given genotype. Recent molecular studies show that the taxonomic composition of natural bacterial communities comprises a tremendous diversity, although relatively few species appear to form the bulk of the biomass (Pedrós-Alió 1993). The enormous genetic potential provides the basis for rapid selection of the best adapted strains to the prevailing selection forces. The high phenotypic plasticity of bacteria further extends the potential response of bacteria to predation pressure. The morphological and physiological flexibility of bacteria has been studied and interpreted mainly in response to environmental changes (see Roszak \& Colwell 1987), especially adaptations to nutrient limitation (e.g. Tempest \& Neijssel 1978) and starvation survival (Kjelleberg 1993). Surprisingly, very few studies have examined the physiological adaptations of bacterial species to predation (e.g. Shikano et al. 1990).

Predator avoidance mechanisms in bacteria gain a strategic advantage when predation is a major selective force. This is presumably not the case for bacterial cells which stay in the nutrient-deficient bulk phase of oligotrophic waters where the availability of energy is the limiting factor for bacterial growth. The dominant life strategy is starvation-survival with a reduced maintenance metabolism, small cell size and slow or no growth (Morita 1982, Kjelleberg 1993), whereas the development of predator avoidance strategies is of minor importance. Further, bacteria in very oligotrophic environments may gain a numerical refuge from grazing because their low numbers are insufficient to support significant grazer populations (Wikner \& Hagström 1991).

However, it is assumed that nutrient-enriched microzones, like aggregates, feces and the surroundings of excreting organisms, are of particular importance in oligotrophic environments (Azam \& Ammerman 1984, Goldman 1984). On aggregates, all microbial components and processes are incorporated in a concentrated form. Larger sized bacteria and abundant protozoans occur in these microzones (Caron et al. 1982) and predation could become an important selection pressure on the bacterial assemblage. Substrate control of bacteria can also be the prevailing controlling mechanism in more eutrophic systems (e.g. Billen et al. 1990, Güde
1993) but nutrient-rich microenvironments and substrate pulses become more frequent. Thus, the relative importance of predation as the selective pressure should increase with the trophy of the environment and some of our considerations regarding the importance of GRB are focused on these situations.

The adaptational capacity of bacterioplankton, on the community and on the species level, combined with potentially high growth rates should allow a rapid succession towards resistant bacteria when predation is a major selective force. This should be especially true when predation by a single guild of grazers predominates. Indeed, heterotrophic nanoflagellates (HNF) have been identified for many freshwater and marine planktonic systems as the major bacterivores (Wright \& Coffin 1984, Güde 1986, McManus \& Fuhrman 1988, Wikner \& Hagström 1988, Sanders et al. 1989).

\section{MECHANISMS OF GRAZING RESISTANCE}

It has to be emphasized that grazing resistance is a relative, rather than an absolute, property and that the degree of grazing resistance depends on a variety of factors. Although an absolute resistance might rarely be achieved, a slightly reduced vulnerability of certain bacterial forms could have profound impacts on their population dynamics. The type of grazer which predominates is certainly an important factor. Reduced vulnerability towards one type of grazer can imply enhanced vulnerability towards other predators as will be exemplified in some cases for protozoans and metazoans as bacterivores. Most of our considerations and evidence, however, will focus on resistance against predation by protozoans, as they seem to be the most ubiquitous bacterial grazers in planktonic environments (e.g. Sanders et al. 1992).

For some predator avoidance mechanisms, the distinction between a passive resistance, which enables the survival of non-growing or slowly growing cells, and the active growth of predation resistant forms can be made. This is outlined in more detail for morphological properties, but is probably also valid for some other resistance strategies.

\section{Morphological properties}

The morphology and size structure of planktonic bacteria is relatively easy to assess by current methodology (epifluorescence microscopy, image analysis). Thus, more information is available on morphological features than on other potential resistance properties of bacteria. It is known that the morphological structure of bacterial assemblages can change on short time 
scales and is influenced mainly by substrate supply and grazing activities (Turley et al. 1986, Krambeck 1988). Size-selective predation is an important mechanism for structuring zooplankton communities (e.g. Brooks \& Dodson 1965) and might play an important role also for the smallest organisms within the planktonic food web.

\section{'Ultramicrobacteria' as a passive resistance}

Natural bacterial assemblages are characterized by the dominance of small cells (generally 0.02 to $0.1 \mu^{3}$ in volume), in contrast to bacterial isolates or even mixed seawater cultures grown in the laboratory, which mostly grow as larger rods and exceed a volume of 0.1 to $0.2 \mu \mathrm{m}^{3}$ (e.g. Ammerman et al. 1984). The discrepancy in the size structure between laboratory cultures and in situ assemblages can be explained by the starvation conditions experienced by planktonic bacteria, which force the development of small, slowly or non-growing cells (Morita 1982, Kjelleberg 1993) and by a continuous selective removal of larger bacteria by grazers in the natural environments (Ammerman et al. 1984). The smallest size classes $(<0.3 \mu \mathrm{m})$ of planktonic bacteria, termed ultramicrobacteria (Torella \& Morita 1981), can form a considerable biomass in oligotrophic waters (Cho \& Azam 1988). Active growth without an increase of cell size has been found only rarely for ultramicrobacteria (Torella \& Morita 1981, Schut et al. 1993) and most are probably in a dormant state (Stevenson 1978).

Much evidence reveals that small sized bacteria are grazed at a lower rate by protozoans. It has been shown in culture experiments (Andersson et al. 1986) and in field observations (Krambeck 1988, KuuppoLeinikki 1990) that the size distribution of bacterioplankton shifts towards the lower end in the presence of bacterivorous flagellates. Higher feeding rates on larger sized particles has been demonstrated first for bacterivorous, filter-feeding ciliates (Fenchel 1980). Moreover, a clear preference for larger sized bacteria was demonstrated when mixtures of differently sized fluorescently labelled bacteria were offered simultaneously to interception-feeding HNF (Chrzanowski \& Simek 1990, Epstein \& Shiaris 1992, Simek \& Chrzanowski 1992).

A dependence of particle uptake efficiency on cell size was also found when the feeding rates on different particle sizes were compared independently. Clearance rates of HNF on bacteria were shown to increase in proportion to the volume (González et al. 1990) or to the radius (Monger \& Landry 1991) of the bacterial cells. Fig. 1 shows the dependence of the relative feeding efficiencies of interception-feeding nanoflagellates

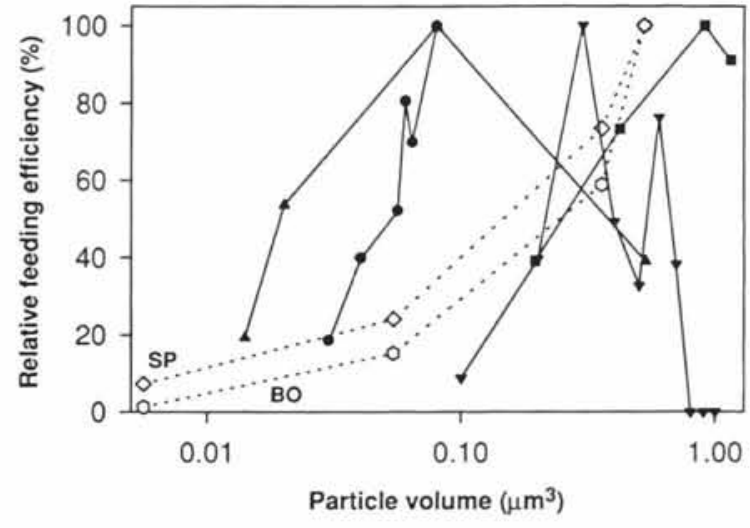

Fig. 1. Relative feeding efficiency $(\%)$ of interception-feeding nanoflagellates with respect to particle volume. Literature data were taken from 4 different studies: $(\rightarrow$ ) González et al. 1990; $(\rightarrow)$ Holen \& Boraas 1991; $(\rightarrow-)$ Monger \& Landry 1992; $(\rightarrow)$ Simek \& Chrzanowski 1992. For comparison the relative feeding efficiencies of 2 nanoflagellates (SP: Spumella sp.i BO: Bodo sp.) on fluorescent microspheres (Polyscience, Inc.) of different sizes are shown (Jürgens unpubl.). The highest clearance rate found in each study was set to $100 \%$. Note logarithmic scale of $x$-axis

on particle size in 4 studies. According to these results, the smallest bacterial cells have a reduced vulnerability to HNF. However, it is difficult to determine from these studies which natural bacterial size classes might constitute a grazing refuge because very different ranges of bacterial sizes were used in these experiments. The bacterial volumes which were considered span nearly 3 orders of magnitude. One reason for these discrepancies might be that factors other than size can be responsible for selection of certain bacteria (Landry et al. 1991, González et al. 1993). Another problem is the potentially large bias of cell size measurements due to the different methods used (Krambeck et al. 1990). This may be overcome by using microspheres of defined diameters. Relative maximum filtration rates for 4 particle sizes $(0.22,0.47,0.88$ and $1.0 \mu \mathrm{m}$ diameter) have been included in Fig. 1, derived from uptake studies with starved HNF, which showed no discrimination of beads compared to bacteria (Jürgens unpubl.). Filtration efficiency increased nearly exponentially with particle volume and microspheres of $0.47 \mu \mathrm{m}$ were ingested at a rate of about $20 \%$ of $1.0 \mu \mathrm{m}$ particles.

Size-selective feeding by direct-interception-feeding flagellates does not require active predator choice and can be explained solely by geometric models of particle encounter probabilities (Fenchel 1982a). These models predict that direct interception of prey particles by a spherical collector is proportional to the square of the prey radius. This was modified by Monger \& Landry (1990), to include hydrodynamic boundary 
effects and van der Waals forces and by Shimeta \& Jumars (1991), to include diffusional deposition. Although the encounter probability models are probably the basis for the observed size-discrimination, actual ingestion rates by HNF might differ also because of more behavioural complexity (see Verity 1991a).

Organisms other than HNF are probably of minor importance as consumers of ultramicrobacteria. Some ciliate species are able to ingest particles down to $0.1 \mu \mathrm{m}$ but with a drastically reduced clearance rate (Fenchel 1980). Only few filter-feeding metazoans can be significant consumers of natural bacteria. These are mainly cladocerans (e.g. Daphnia) in lakes (e.g. Porter et al. 1983, Brendelberger 1991) and appendicularians in marine systems (King et al. 1980, Flood et al. 1992). The retention efficiency in Daphnia decreases rapidly for bacteria less than $0.5 \mu \mathrm{m}$ (Brendelberger 1991) and both Daphnia and appendicularians occur only seasonally and not in all systems in high numbers.

Small size does not achieve an absolute grazing resistance for natural bacteria. Nanoflagellates have been shown to be able to ingest microspheres of less than $0.1 \mu \mathrm{m}$ (Marchant \& Scott 1993) and even viruses (González \& Suttle 1993) and macromolecules (Sherr 1988, Marchant \& Scott 1993, Tranvik et al. 1993). However, the probability of capture decreases for small cells, and this relative grazing resistance might be sufficient to survive periods of unfavourable conditions without cell multiplication. In summary, miniaturisation of cell size can be considered mainly as an adaptation to severe carbon limitation. Concomitantly, however, this adaptation reduces the risk of being consumed by bacterivores and thus constitutes a predation defense without extra costs. In contrast, actively growing bacteria have to increase in cell size and thus become more vulnerable to predation (Sherr et al. 1992). No estimation of this relative grazing resistance of ultramicrobacteria has been done yet. Therefore their potential survival time in natural waters cannot be estimated at present.

\section{Morphologically complex growth forms}

A variety of bacterial growth forms exists which can not be ingested by the majority of small phagotrophic protozoans due to their morphology. Among those forms, which mostly exceed the size of HNF, are filaments, spiral-shaped and star-like cells, and aggregations and clumps of smaller cells. Strong grazing pressure by protozoans can cause shifts in bacterial populations from a predominance of small, freely dispersed single cells to such complex growth forms (Güde 1979). This has been observed first in sewage treatment processes where bacterial flocculation was suggested to result from the selective removal of dispersed bacteria by protozoans (reviewed by Curds 1982). In chemostat experiments with inocula from activated sludge systems, the grazer-dependent development of aggregates and filaments was demonstrated by Güde $(1979,1982)$, but similar observations have also been made in experimental protozoan/bacteria systems in sea or in lake water (van Wambeke \& Bianchi 1985, Caron et al. 1988, Bianchi 1989).

The observed pattern suggests that free single cells are selected when competition for substrates is the only selection factor. But these cells are most susceptible to protozoan grazing and are therefore replaced by grazing-resistant, more complex growth forms when grazing pressure exceeds a certain level. The change in population size structure can be accompanied by a change in species composition and the appearance of morphologically peculiar forms like Microcyclus sp. (Güde 1979) and Ancalomicrobium (Bianchi 1989). However, an alteration of the species composition need not necessarily be involved. Some bacterial species seem to have a high phenotypic plasticity which enables them to change their morphology under certain conditions (Güde 1979). This was also demonstrated by Shikano et al. (1990) for a bacterium which could increase in length from $1.5 \mu \mathrm{m}$ to $20 \mu \mathrm{m}$ when exposed to predation by the ciliate Cyclidium sp. Although environmental factors, like medium composition, substrate source and temperature, can be responsible for the development of long filaments in some bacterial strains (e.g. Patel et al. 1979), this morphological change has to be seen also in the context of anti-predator defenses. Morphologically complex bacteria generally cannot be ingested by nanoprotozoans although there are exceptions, such as certain sewage ciliate species which are specialised to prey on large filaments (Inamori et al. 1991). Which type of grazing-resistant growth forms (e.g. aggregates or filaments) becomes predominant under protozoan predation seems to depend partly on the composition of the available substrates (Güde 1989).

The above-mentioned studies have 2 features in common which are important for the interpretation of situations where morphologically resistant bacteria occur. First, the substrate supply was generally enhanced, compared to the natural situation, by addition of organic carbon. This suggests that under very low substrate concentrations morphologically complex growth forms like filaments and aggregates could have difficulties in meeting their growth demands. The second characteristic of experiments where morphologically inedible bacteria developed is that protozoans (flagellates and ciliates) were always nearly the exclusive bacterial grazers. When larger metazooplankton are also present, the outcome may be quite different. 
First, bacterial aggregates and other complex growth forms are more suitable food particles for larger detrital consumers and filter feeders (e.g. Schoenberg \& Maccubin 1985, Lawrence et al. 1993) and are directly consumed. Second, metazoan predation on protozoans reduces the grazing pressure on small bacteria.

The effects of protozoan and metazoan predation on the bacterial community structure were compared in laboratory microcosm experiments with a mixed bacterial lake water culture, nanoflagellates and metazooplankton (Jürgens et al. unpubl.). The growing bacterial population, supplemented with glucose, was exposed for $24 \mathrm{~h}$ to predation by HNF alone or by both Daphnia magna and HNF. In both cases the bacteria were reduced to a similar low level. But the remaining bacterial assemblage after $24 \mathrm{~h}$ of protozoan grazing consisted of more than $80 \%$ of GRB (aggregates and filaments). In the presence of D. magna, which can feed on flagellates and probably also on most morphological types of bacteria (Güde 1988), the remaining bacterial population resembled the original one, with free single cells predominating (Fig. 2). Thus we conclude that the grazing resistance of complex growth forms is an appropriate solution when small protists are the main predators but not when significant grazing by metazooplankton also occurs. The importance

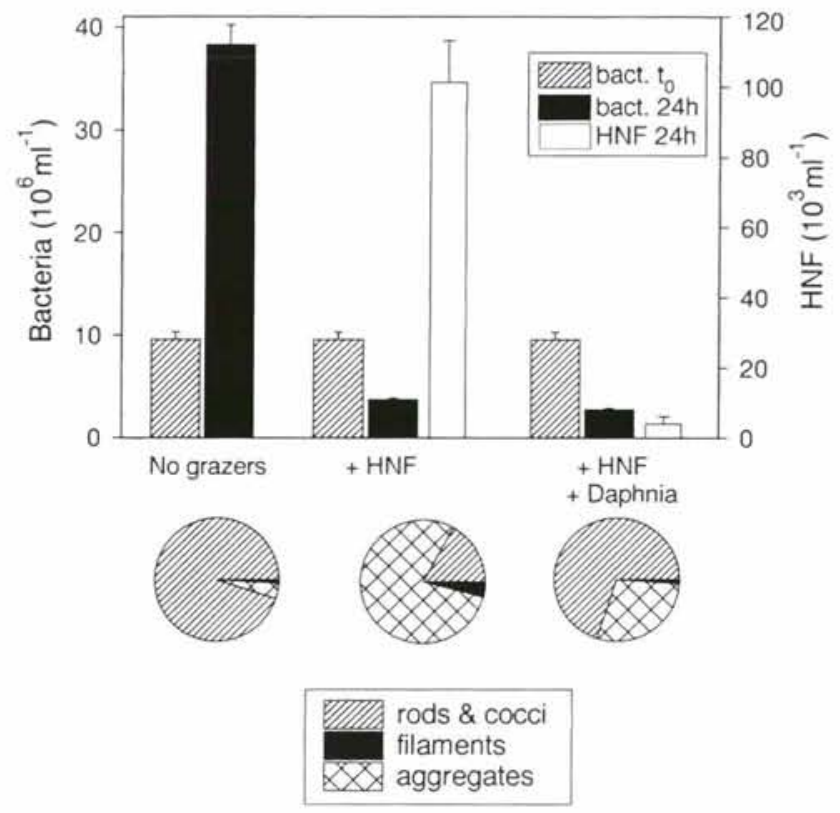

Fig. 2. Results of a bacterial grazing experiment (Jürgens et al. unpubl.). A mixed bacterial culture grown in a C-limited chemostat was transferred to batch culture, supplemented with $20 \mathrm{mg}$ glucose $1^{-1}$ and inoculated with HNF (heterotrophic nanoflagellate, Spumella sp.), with HNF and Daphnia magna (100 ind. $\left.1^{-1}\right)$ or left without grazers. The upper graph shows the bacterial and HNF numbers after $24 \mathrm{~h}$. Below, the relative bacterial biomass distribution into 3 distinct morphotypes after $24 \mathrm{~h}$ is shown of these findings for the natural situation will be discussed later.

\section{Chemical properties}

Among the interactions between phytoplankton and zooplankton grazers, considerable evidence for chemically mediated grazing resistance of certain algal species has accumulated, e.g. indigestibility and undamaged gut passage of certain green and blue-green algae (Porter 1973) and inhibition of zooplankton filtering activity (Lampert 1981). In analogy to these interactions, similar mechanisms should be expected also for bacterioplankton. However, corresponding experimental studies are still scarce. Evidence for chemical resistance comes more indirectly from laboratory growth experiments with bacterivorous protozoans and from studies on host-pathogen interactions in medical microbiology.

A number of authors have reported different growth efficiencies of bacterivorous protozoans in dependence on the bacterial species offered. This has been shown in laboratory experiments with amoebae (Singh 1941), nanoflagellates (Sherr et al. 1983, Mitchell et al. 1988, McGinnes \& Johnson 1992) and ciliates (Curds \& Vandyke 1966, Barna \& Weis 1973, Taylor \& Berger 1976). Some of the bacterial strains used in these studies did not support growth of the protozoans at all or even produced toxic effects (Curds \& Vandyke 1966, Barna \& Weis 1973). Because generally these strains were not morphologically distinct from bacterial strains which supported growth of the protozoans, these findings suggest the existence of some kind of chemical resistance. This cannot be proven, however, until the fate of ingested cells has been followed in more detail. The biochemical composition of the bacterial prey might simply limit protozoan growth without lowering the vulnerability of the bacteria towards ingestion and digestion.

Whereas the survival strategy of morphologically resistant bacteria aims at avoiding ingestion, chemical resistance might involve reduced digestion and assimilation following ingestion. The fate of bacteria preyed upon by protozoans is probably to a large extent determined after the ingestion process, which can be rather unselective and independent of the nutritional value of the food particles (Dubowsky 1974). Studies regarding this aspect in the interactions between bacteria and bacterivores have dealt mainly with enteric and pathogenic bacteria because of the general public health aspects. Very different digestion times have been found, for example, for Enterococcus feacalis and Escherichia coli despite similar ingestion rates by a natural protozoan community (González et al. 1990). 
The undamaged gut passage of natural heterotrophic bacteria inside different planktonic metazoans, e.g. Daphnia ambigua (King et al. 1991) and Calanus pacificus (Lawrence et al. 1993), has been reported.

The phagocytosis of pathogenic bacteria by protozoans has received some attention because of possible similarity with the uptake and killing of microorganisms by phagocytic cells in the host defence of higher organisms (Lock et al. 1987). For several pathogenic bacterial strains, the undamaged survival and sometimes even proliferation inside bacterivorous protozoans has been shown, for example for Vibrio cholerae inside 2 species of amoebae (Thom et al. 1992), and for several coliform bacterial strains (King et al. 1988) and Listeria spp. (Ly \& Müller 1990) inside the amoebae Acanthamoeba castellani and the ciliate Thetrahymena pyriformis. King et al. (1988) speculated that resistance to protozoan digestion is an evolutionary precursor of pathogenicity in bacteria. Survival in a protective and nutrient-rich microenvironment inside some protozoan species could be another survival strategy of natural bacteria (King et al. 1988). Thus, resistance to digestion is a potentially widespread mechanism in natural bacteria.

The factors which influence the digestibility and assimilation of ingested bacteria are only poorly known. There are indications of an inferior food value of Gram-positive bacteria (e.g. Bacillus subtilis) for various ciliates (Taylor \& Berger 1976) and of sulfurcontaining bacteria (Chlorobium phaeobacteroides, Thiocapsa roseopersicina) for acidophilic flagellates (McGinnes \& Johnson 1992). The physiochemical properties of the surface membranes of bacteria are certainly crucial for the phagocytosis process (van Oss 1978). One important parameter is the bacterial cellsurface hydrophobicity. It has been shown to promote adhesion to surfaces and to be a response to starvation conditions (Kjelleberg \& Hermansson 1984). Evidence that surface hydrophobicity influences phagocytosis comes from studies on the ingestion of pathogenic bacteria (e.g. Staphylococcus and Salmonella) by phagocytic cells of the human immune system. Several authors have reported that the hydrophobicity of the tested bacterial strain was positively correlated to the ingestion rate by phagocytic cells (Cunningham et al. 1975, Absolom 1988, Marodi et al. 1990). Because of similarity with the ingestion process of bacterivorous flagellates, comparable results can be expected. In preliminary experiments with differentially coated microspheres, it became indeed evident that increased hydrophobicity of the particles strongly increased the clearance rate of nanoflagellates (M. Landry pers. comm.).

The molecular composition of bacterial cell walls can be considered plastic and responsive to the bacterial growth environment (Ellwood \& Tempest 1972) and could constitute a key factor for the phagocytosis process. So far, detailed studies on the phenotypic plasticity of bacterial cell walls have been conducted only to examine responses to environmental growth conditions but not to protozoan grazing pressure.

Exopolymer secretion (EPS) has been found in many bacteria and serves different functions which enhance the survival and competitive success of microbes (reviewed by Decho 1990). These include the formation of a favourable microenvironment which facilitates attachment, maintains activity of exoenzymes, sequesters nutrients and protects against toxins (Decho 1990). Capsular secretions may also prevent efficient uptake by nanograzers and could act, after ingestion, as a barrier which slows down the penetration of digestive enzymes. The formation of extracellular products has been observed in P-limited mixed bacterial cultures where it probably reduced the extent to which the bacterial population was grazed by HNF (Jürgens \& Güde 1990). Because EPS secretion is dependent on an excessive carbon supply (Decho 1990), this potential grazing resistance mechanism is probably less relevant in the bulk water phase. It could be important, however, inside detritus aggregates, where the formation of bacterial exopolymers has been noted (Biddanda 1985).

\section{Motility}

Behavioural properties of pelagic bacteria which might influence the vulnerability to grazers is probably confined to motility. Bacterial motility, in combination with chemotactic behaviour, could help to locate microzones of high organic substrate concentrations (Azam \& Ammerman 1984) and thereby increase the competitive ability of natural bacteria (Lauffenburger 1991). The importance and frequency of motility among natural bacterioplankton is not well studied and restricted to a few observations. Azam \& Cho (1987) reported that 5 to $30 \%$ of the bacteria in concentrated marine samples were motile, with mean swimming speeds of 20 to $40 \mu \mathrm{m} \mathrm{s}^{-1}$.

Motility of a bacterial cell would increase the encounter rate with a direct-contact feeding flagellate. Diffusion feeding rates (of non-motile flagellates) could equal the direct-interception-feeding rates (of motile flagellates) if all bacterial prey were motile (Fenchel 1984). The effect of motility on capture rate can be evaluated when comparing grazing on motile and non-motile forms of the same bacterial species. This was done by Monger \& Landry (1992) and González et al. (1993) who both found 2 to 4 times higher clearance rates of HNF grazing on a motile 
bacterium compared to a non-motile (heat-killed) form. Contrary to these findings, Mitchell et al. (1988) observed higher growth rates of Bodo saltans on nonmotile bacterial strains than on flagellated, motile bacteria. However, in this case it could have been also due to other properties (e.g. the chemical composition) of the different bacterial strains used.

It has been reported that during carbon starvation, rod-shaped motile cells become small, coccoid and nonmotile (Holmquist \& Kjelleberg 1993). Presumably motility and chemotaxis are lost by small, starving bacterial cells. If motility is restricted to bacteria which are in an actively growing state, it means that their enhanced vulnerability due to their larger size is further increased.

\section{Spatial refuges}

The concept of bacterial growth in spatial refuges has been developed mainly from studies of bacteriaprotozoan interactions in soil and sediments. The pore size of soil aggregates is obviously an important factor influencing the accessibility of bacteria to grazers (Vargas \& Hattori 1986, England et al. 1993).

In pelagic environments, the majority of the bacteria are freely suspended and obviously without a spatial refuge. However, attached bacteria, although minor in numbers, can constitute a significant fraction of the total bacterial biomass and activity (e.g. Pedrós-Alió \& Brock 1983a). As mentioned in the 'Introduction', nutrient-enriched microaggregates can be spots of high activity and increased predation pressure. Some species of flagellates and ciliates are specialised to feed on bacteria inside aggregates (Caron 1987, Sibbald \& Albright 1988). The origin and physical structure of the particles, and the location of the bacteria within the particle, may affect whether particles can serve as a refuge. In fact, suspended solids were shown to harbor higher bacterial concentrations than the surrounding water (e.g. Goulder 1976), and attachment to particles has been found to be an effective survival mechanism of Escherichia coli cells which were released in lake water (Brettar \& Höfle 1992). Particleassociated bacteria might be less vulnerable to protozoan grazing but they can be ingested efficiently by many metazooplankters (Schoenberg \& Maccubin 1985, Lawrence et al. 1993).

Bacterial growth in biofilms, where grazing can be strongly reduced, is important in lotic and benthic habitats (Lock et al. 1984) but not in pelagic waters. For a spatial refuge on a larger scale, we have to also consider parts of the water body which are less populated by predators. One example is the anaerobic hypolimnion of eutrophic lakes during stratification. Here, bacterial numbers and cell volumes are generally increased compared to the epilimnion due, in part, to reduced predation by bacterivorous protozoans (Fenchel \& Finlay 1991, Cole et al. 1993, Pedrós-Alió \& Guerrero 1993).

\section{INTERPRETATION OF FIELD DATA}

Field studies on bacteria-grazer interactions have generally focused on assessing the abundances of bacteria and protists and on the measurement of bacterial production and grazing losses. Little is known about how grazing can impact and alter the composition of bacterial communities. One indirect support for the GRB concept comes from the relative stability of bacterioplankton standing stock within a given system. Additional evidence can be derived from the study of microbial successions in microcosms which we summarize below. Direct observations of GRB in natural waters are mainly restricted to morphologically complex growth forms, for which we will present some examples.

\section{Population dynamics of bacterioplankton}

Some considerations about the potential importance of GRB gain support from data on the abundance and seasonal dynamics of bacteria and their main predators, heterotrophic nanoflagellates. In the earlier microbial loop studies it was postulated that the constant low numbers of bacteria in the ocean are maintained by grazing activities (e.g. Ducklow 1983, Fenchel 1984). However, bacterial concentrations which are between $10^{5}$ and $10^{6}$ cells $\mathrm{ml}^{-1}$, and thus below a possible threshold level for HNF growth (Fenchel 1982b, Wikner \& Hagström 1991), are restricted to the most oligotrophic environments where bacteria are severely substrate limited. In meso- to eutrophic lakes and coastal areas, bacterial concentrations during the growing season are generally between 5 and $10 \times 10^{6} \mathrm{ml}^{-1}$ (Bird \& Kalff 1984). Although population regulation occurs generally by a balancing of 'bottom-up' food limitation and 'top-down' predation effects (Oksanen et al. 1981, Leibold 1989), there is strong empirical and experimental evidence that the standing stock of bacterioplankton is mainly determined by bottom-up limitation, i.e. the substrate supply of the system (Cole et al. 1988, Billen et al. 1990, Güde 1993).

The low seasonal variation in bacterial density compared to other plankton organisms is well known (e.g. Wright \& Coffin 1984). This is especially obvious when excluding the winter values, where bacterial growth is constrained by temperature. For a comparison of phyto- 


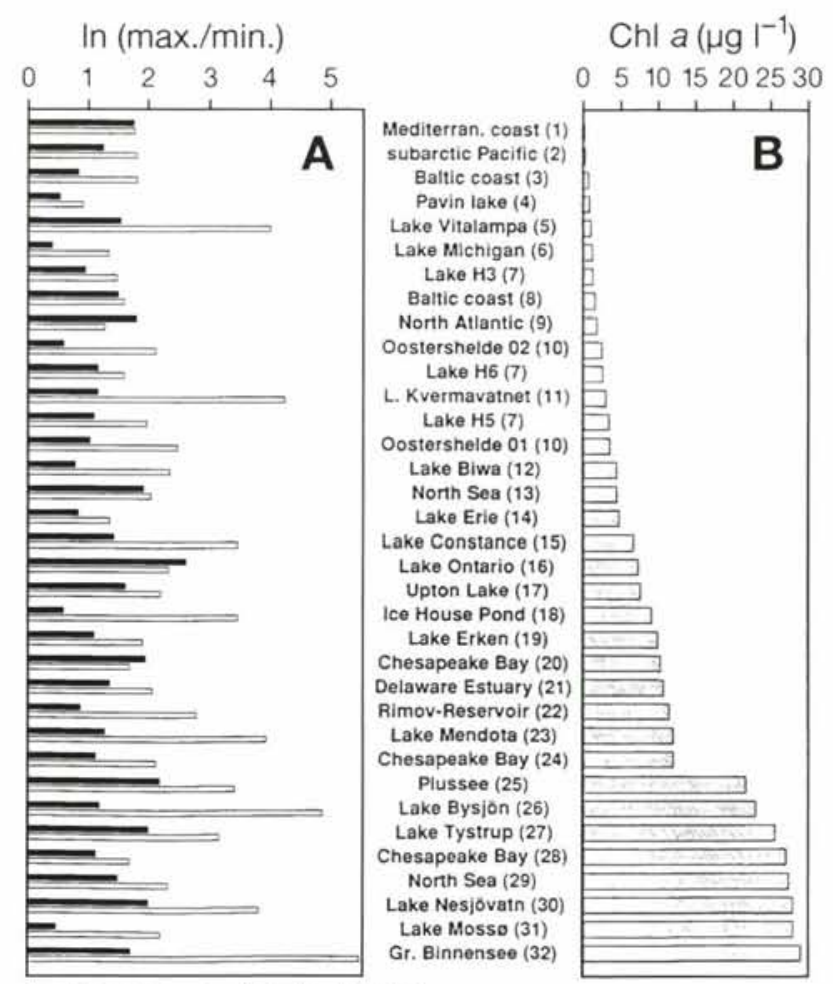

Bacteria $\square$ Phytoplankton

Fig. 3. (A) Fluctuations in phytoplankton and bacteria during the growing season in various freshwater and marine systems. Original data for phytoplankton were expressed as chlorophyll $a$ or biomass and for bacteria as cell number or biomass. Only values during the growing season (approximately between April/May and October/November) were considered, where temperatures were generally above $10^{\circ} \mathrm{C}$. Ratio of maximum to minimum value (as natural logarithm) is shown. (B) Mean chlorophyll $a$ concentration as a trophic indicator for the systems during the period considered for $(\mathrm{A})$. When only biomass data were given, chl a was estimated by assuming a ratio of chl $a: C$ of 50 . Data from the following sources were used: (1) Velimirov \& Walenta-Simon (1992); (2) Kirchman et al. (1993); (3) Kivi et al. (1993); (4) Amblard et al. (1993); (5) Johansson (1983); (6) Scavia \& Laird (1987); (7) Hessen (1985); (8) Larsson \& Hagström (1982); (9) Ducklow et al. (1993); (10) Laanbroek et al. (1985); (11) Børsheim et al. (1988); (12) Nagata (1987); (13) Billen \& Fontigny (1987); (14) Lean et al. (1983); (15) Güde et al. (1985); (16) Rao et al. (1979); (17) Pace et al. (1990); (18) Kirchman (1983); (19) Bell \& Kuparinen (1984); (20) Malone et al. (1986); (21) Hoch \& Kirchman (1993); (22) Simek et al. (1990): (23) Pedrós-Alió \& Brock (1983b); (24) Malone et al. (1991); (25) Meier (1991); (26) Coveney et al. (1977); (27) Riemann (1983); (28) Jonas \& Tuttle (1990); (29) van Boekel et al. (1992); (30) Vadstein et al. (1988); (31) Riemann et al. (1982);

(32) Jürgens \& Stolpe (in press)

plankton and bacterioplankton variation throughout the growing season, we used from literature reports only the data between April/May and October/ November, thus most of the values were from water temperatures above $10^{\circ} \mathrm{C}$. Fig. 3 shows the total variation (maximum value/minimum value) of bacteria and phytoplankton for each system, listed in order of in- creasing chlorophyll concentration. Additionally, the summary statistics of marine and freshwater data are given separately in Table 1. Most available data are from lakes and coastal estuaries. Few off-shore data could be included because of the lack of seasonal studies. Although for most studies only chlorophyll a and bacterial numbers were available, and not measured biomass, these data are sufficient to demonstrate the different seasonal dynamics. The freshwater data show, with one exception for Lake Ontario, a consistently higher variation in phytoplankton than in bacteria. For marine systems this tendency is not so clear (9 out of 13 studies with higher phytoplankton variation), possibly caused by an overrepresentation of oligotrophic systems. Phytoplankton variation is especially high in meso- to eutrophic lakes where more than half of the systems shown in Fig. 3 vary between 20- and 150-fold, whereas concomitant changes of bacterial standing stock vary between 1.5- and 9-fold. The highest seasonal variation occurs in lakes with variable populations of cladocerans. There, clearwater phases with chlorophyll minima and dense algae blooms can be found within one season (Lampert et al. 1986).

The empirical data outlined above point to a much higher buffering of bacterioplankton populations than for other planktonic organisms. Many predator-prey relationships in aquatic systems are characterized by strong, temporal instabilities. For example, fish or insect predators in some lakes can drive larger zooplankton species extinct (Brooks \& Dodson 1965) and herbivorous zooplankton (e.g. Daphnia) can temporarily almost eliminate small edible phytoplankton (Lampert et al. 1986).

Similar predation impacts on bacteria, where bacterial numbers change from peaks down to levels comparable to the winter situation, have only rarely been reported (e.g. Rao et al. 1979). The relative seasonal constancy of bacterial numbers has been attributed to a constant balancing of bacterial production by grazing protozoans (Azam et al. 1983, Wright $\&$ Coffin 1984). However, there remain some objections to the role of HNF as controlling agents of planktonic bacteria. Although it has been shown that HNF numbers increase with the trophy of the system (Sanders et al. 1992), seasonal HNF fluctuations are much higher than those of bacteria, especially in more eutrophic systems (Fenchel 1984, Jürgens 1992, Gasol \& Vaqué 1993). Strong fluctuations in HNF abundance, which were probably mainly governed by a change in metazoan predation, were often without any resulting changes in bacterial abundance (e.g. Jürgens \& Güde 1991, Weisse 1991). Typical predatorprey oscillations between bacteria and HNF seem to be an exception (e.g. Andersen \& Sørensen 1986). 
Table 1. Seasonal variation of bacteria and phytoplankton. Summary statistics of the literature data shown in Fig. 3

\begin{tabular}{|c|c|c|c|c|c|c|c|c|}
\hline & \multicolumn{4}{|c|}{ Freshwater } & \multicolumn{4}{|c|}{ Marine } \\
\hline & $\mathrm{n}$ & Mean & SD & Range & $\mathrm{n}$ & Mean & $\mathrm{SD}$ & Range \\
\hline \multicolumn{9}{|l|}{ Bacteria } \\
\hline Max./min. & 24 & 4.2 & 2.9 & $1.4-13.8$ & 13 & 4.2 & 1.7 & $1.8-6.9$ \\
\hline $\mathrm{CV}(\%)$ & 24 & 33.9 & 14.6 & $11.2-64.8$ & 13 & 39.9 & 12.8 & $18.8-72.5$ \\
\hline \multicolumn{9}{|c|}{ Phytoplankton } \\
\hline Max./min. & 24 & 39.8 & 57.6 & $2.5-244.5$ & 13 & 7.2 & 2.3 & $3.6-12.0$ \\
\hline CV (\%) & 24 & 70.2 & 28.2 & $30.1-141.3$ & 13 & 55.1 & 17.2 & $20.8-132.2$ \\
\hline
\end{tabular}

\section{Microbial succession in microcosms}

Numerous studies, mostly from marine systems, have been designed to examine the decomposition of natural particulate or dissolved organic substrates and the resulting successions of the microbial communities. A general feature of these studies was the addition of an organic carbon source to sea or lake water which stimulated the development and succession of heterotrophic bacteria and

Considering the large concentration and biomass of bacterioplankton in more eutrophic systems, bacteria seemed to be often a rather minimally exploited food resource for HNF (Jürgens 1992). A study on eutrophic lakes and ponds revealed that the majority of the planktonic bacteria were in the smallest size classes $\left(<0.02 \mu \mathrm{m}^{3}\right)$, the number of larger bacteria $(>0.5 \mu \mathrm{m})$, however, was found to be sufficiently high ( 3 to $7 \times 10^{6} \mathrm{ml}^{-1}$ ) for nearly maximal growth rates of HNF (Jürgens 1992). These findings implied that grazers were obviously not efficiently controlling bacterial numbers although their feeding activity may balance bacterial production.

Unfortunately we do not know with sufficient confidence how close natural bacterial assemblages approach the carrying capacity of the environment. The growth of bacteria in the absence of grazers, as achieved by $1 \mu \mathrm{m}$ filtration and bottle incubation (Wright \& Coffin 1984) can be subject to artefacts, as indicated by pronounced lag-phases (Güde et al. 1991), and has to be interpreted with caution.

There are 2 alternative hypotheses to the conclusion that bacterial biomass is not efficiently exploited by bacterivores. First, predators on HNF (ciliates and metazoans) could keep HNF at low densities, thereby enabling higher bacterial concentrations (Wright 1988). This is certainly true in many situations, well documented for example when Daphnia dominates the metazoan community (Riemann 1985, Güde 1988, Pace et al. 1990). However, relatively small numbers of bacterivorous protists were even found when predation pressure on HNF was estimated to be low (Jürgens \& Güde 1991) and it is not very probable that nanoplanktonic protists are consistently predator controlled. The other (or additional) explanation would be that increased grazing pressure is followed by the development of GRB. Only a part of the bacterioplankton may be edible and an unknown proportion may have acquired some kind of grazing resistance. This would buffer against strong increases in predator populations, compensate grazing losses, and stabilize the standing stock of bacterial biomass. protozoans. Despite very different experimental conditions, including substrate source, medium, temperature and incubation time, a general succession pattern can be extracted from all these studies and interpreted with respect to the development of GRB. The 3 main sequences with the development of the major organism groups in this succession are schematically shown in Fig. 4.

In the initial phase I, substrate addition stimulates bacterial growth and free single-celled, rod-shaped bacteria increase rapidly and consume the available dissolved substrates. Bacterial diversity is generally decreasing during this process and few cell types dominate. In phase II, bacterivorous nanoflagellates develop with high growth rates. They consume the majority of the initial free bacterial assemblage and only attached bacteria and very small cocci remain. Bacterial biomass is strongly reduced and can reach minimum levels depending on the grazing pressure. But when sufficient substrate supply is maintained, bacterial numbers increase again in phase III to a second peak despite the continued presence of protozoans. Therefore this bacterial assemblage seems to be less vulnerable to protozoan grazing. The bacterial

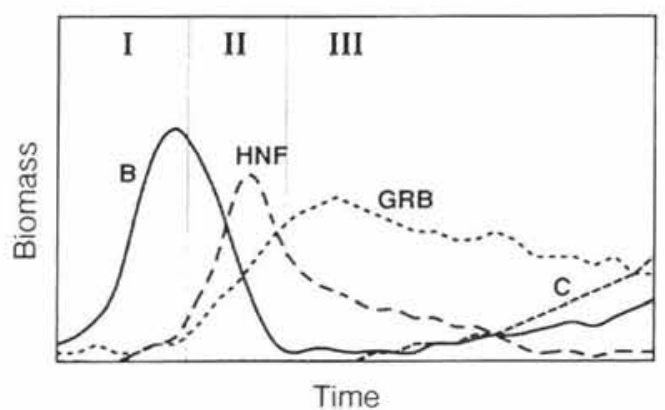

Fig. 4. Schematized microbial succession in microcosm studies (listed in Table 2), which were supplemented with an organic substrate source and where metazooplankton was removed by filtration. Division in 3 main succession sequences (I, II, III) is explained in the text. B: highly edible bacteria; GRB: grazing-resistant bacteria; HNF: heterotrophic nanoflagellates; $\mathrm{C}$ : ciliates 
community structure has changed compared to phase I, new forms have appeared and a morphologically more complex bacterial community develops. The bacterial taxonomic diversity increases again in phase III (e.g. Painting et al. 1989) and larger protozoans appear.

Although predation-resistant bacteria were not the focus of these studies, there are many indications that the second bacterial peak in some of these microcosm experiments consisted of cells which were less accessible to protozoans. Observations on the bacterial assemblage in the different studies, which are probably related to a development of GRB, are listed in Table 2. Most of the evidence refers to morphologically inedible bacteria as large rods, complex growth forms like stalk-like caulobacters and filaments, bacteria in aggregates or attached to particles and small cocci. However, they are only the most obvious forms and other grazing-resistance mechanisms (e.g. chemical resistance) might have been also present.

The bacterial succession during decomposition of particulate organic matter has been attributed mainly to a change in substrates and a corresponding sequence of specifically adapted species during the decomposition process (Fukami et al. 1985, van Wambeke \& Bianchi 1985, Lucas 1986). Although external factors, e.g. amount and composition of substrates and temperature, are certainly important for the species selection, it seems likely that predation by protozoans is at some stages another crucial structuring force for the bacterial assemblage. To verify the role of grazing in changes in bacterial community structure, bacterial succession must be compared to controls where proto- zoans were eliminated. In one such study which examined the decomposition of natural macrophyte detritus in lake water (M. Sala \& H. Güde unpubl.), complex bacterial growth forms, e.g. aggregates, attached bacteria and filaments, developed only in treatments with protozoans, and not in treatments in which the inoculum was kept protozoan-free. In the protist-free treatments, the POC degradation process was comparable but freely suspended bacteria remained dominant.

\section{Field evidence for grazing-resistant bacterioplankton}

Direct observations of GRB in natural waters are restricted to those forms which are most obvious from the phenotypic variations observable with epifluorescence microscopy, e.g. morphologically complex growth forms like filaments and aggregates. A focus on the morphological composition ignores other features, especially the chemically mediated resistance properties, and may therefore reveal only a small proportion of the GRB. Nevertheless, an estimation of this group of GRB can already yield some insights into the potential importance (in terms of biomass) and regulating factors.

The occurrence of complex bacterial growth forms like aggregates, filamentous and star-shaped bacteria during certain periods has been documented from lakes (Güde et al. 1985, Schmaljohann et al. 1987), estuarine environments (Sieburth 1984) and oceanic macroaggregates (Caron et al. 1982). It can coincide with phytoplankton blooms but, more frequently, with periods of intensive grazing by HNF (Güde et al. 1985).

Table 2. Possible grazing-resistant bacteria (GRB) observations in microcosm decomposition studies

\begin{tabular}{|c|c|c|c|}
\hline System & Organic carbon source & Possible GRB in phase III & Source \\
\hline $\begin{array}{l}\text { Mineral media, activated } \\
\text { sludge inocula (chemostat) }\end{array}$ & Polymeric substrates & Filaments, spiral-shaped Microcyclus & Güde (1979) \\
\hline Filtered seawater & Phytoplankton debris & $\begin{array}{l}\text { Thread-like strands, fimbriae, } \\
\text { stalk-like Caulobacter, large } \\
\text { rods, aggregates, attachment }\end{array}$ & Newell et al. (1981) \\
\hline Filtered artificial seawater & DOC (seagrass extract) & Aggregates, attachment & Robertson et al. (1982) \\
\hline $\begin{array}{l}\text { Mineral media, activated } \\
\text { sludge inocula (chemostat) }\end{array}$ & Polymeric substrates & Floc-forming zoogloeal bacteria & Güde (1982) \\
\hline Filtered seawater & DOC (seaweed extract) & Aggregates, attached bacteria & Biddanda (1985) \\
\hline Natural seawater & $\begin{array}{l}\text { Freeze-thaw killed } \\
\text { phytoplankton culture }\end{array}$ & Aggregates & $\begin{array}{l}\text { Biddanda \& Pomeroy } \\
\text { (1988) }\end{array}$ \\
\hline Natural seawater & $\begin{array}{l}\text { Daily enrichment with } \\
\text { prawn food }+ \text { yeast }\end{array}$ & Filaments, prosthecate bacteria & Rault et al. (1988) \\
\hline Synthetic seawater medium & Glucose & Filaments, aggregates & Caron et al. (1988) \\
\hline Filtered seawater (upwelling) & No addition & Small cocci, large rods (Flavobacteriaceae) & Painting et al. (1989) \\
\hline Filtered seawater & Organic matter & Star-like Ancalomicrobium, filaments & Bianchi (1989) \\
\hline Filtered lake water & DOC (algal extract) & Very small cocci & Hadas et al. (1990) \\
\hline
\end{tabular}


The appearance of large numbers of filamentous bacteria bas been quantified by Sime-Ngando et al. (1991) for a humic Canadian and a eutrophic French lake. In this study the filamentous forms contributed more than $70 \%$ of the total bacterial biovolume. This is an extreme case, but filamentous bacteria as well as other complex growth forms can be observed in a variety of meso- and eutrophic lakes during certain periods (Jürgens \& Güde unpubl, data). One example in which the development of larger numbers of filamentous bacteria was highly correlated to the summer maxima of HNF is shown in Fig. 5. During a short period, grazingresistant bacteria in this shallow eutrophic lake comprised up to $40 \%$ of the total bacterial biomass (Jürgens \& Stolpe in press). The fact that freely dispersed, small bacteria did not decrease during the HNF peak might indicate that these represented, in part, also other types of GRB.

An even more drastic example for the rapid development of GRB was seen in an enclosure experiment in a mesotrophic lake in which the zooplankton community was manipulated (Jürgens et al. 1994). The removal of Daphnia spp. from the system resulted in a mass appearance of phagotrophic protozoans which consumed the major portion of the initial bacterial community and initiated a bloom of filamentous bacteria $(>10$ $\mu \mathrm{m}$ in length). After $3 \mathrm{~d}$, filaments comprised more than $80 \%$ of the bacterial biomass (Fig. 6). This study clearly demonstrated that cascading trophic interactions can substantially alter the bacterial assemblage.

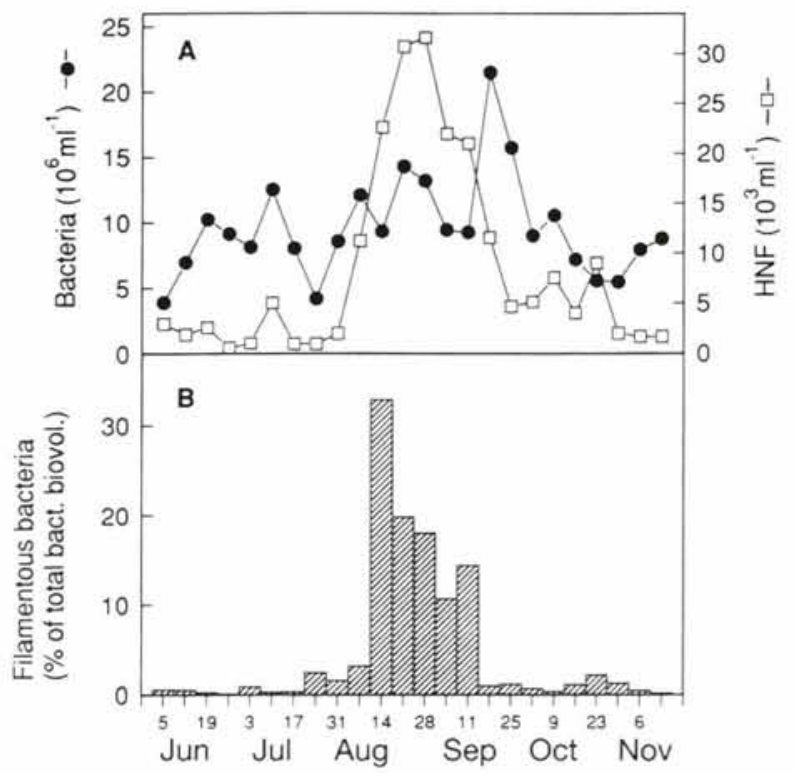

Fig. 5. Seasonal development of bacteria and heterotrophic nanoflagellates (HNF) in Grosser Binnensee (Germany) in 1991 (0.5 m depth). (A) Total abundance of heterotrophic bacteria and HNF. (B) Relative proportion of filamentous bacteria $(\%)$ to total bacterial biovolume

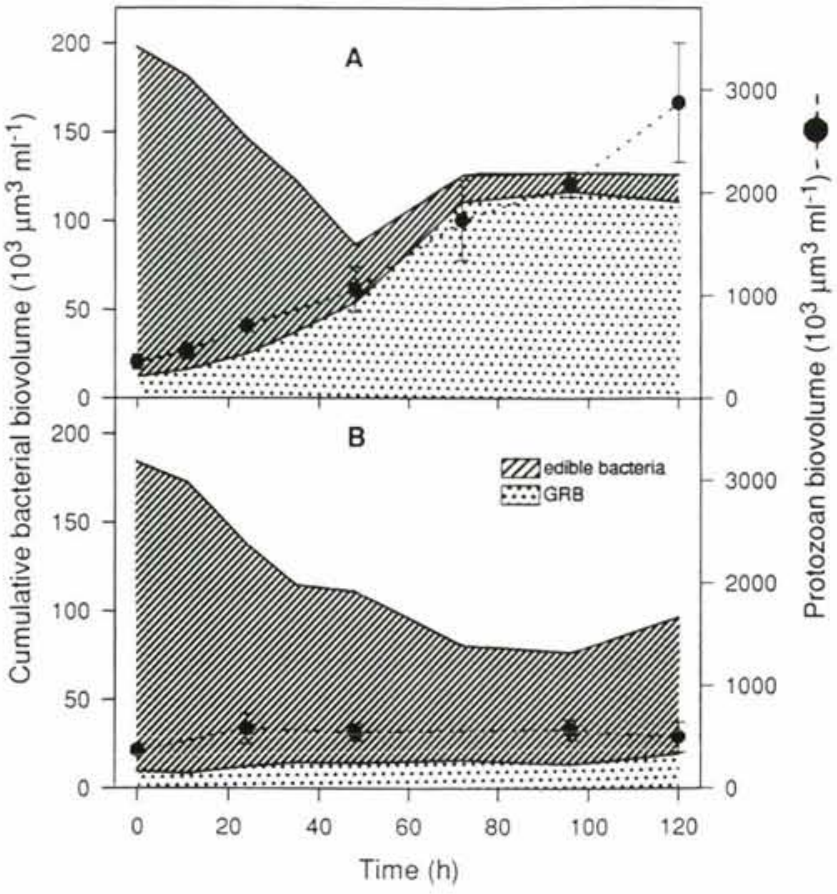

Fig. 6. Development of protozoan-edible bacteria (freely dispersed rods and cocci), grazing-resistant bacteria (GRB; filaments and aggregates), and total protozoan biomass (-) during the course of an enclosure experiment in a mesotrophic lake (Jürgens et al. 1994). Metazooplankton was manipulated by prefiltration. (A) Zooplankton were virtually absent or consisted only of copepods (mean of $n=4$ ). (B) Zooplankton consisted almost exclusively of daphnids (ca 25 ind. $1^{-1}$, mean of $n=2$ )

Such alterations of bacterial populations might be less visible in more oligotrophic systems, as indicated by a comparable study of Pace \& Funke (1991), where the removal of crustacean zooplankton had no obvious effect on the bacterioplankton.

Direct observation of GRB in planktonic habitats might also include the temporal appearance of bacterial species of peculiar morphology. Taxa such as Caulobacter, Ancalomicrobium, Planktomyces and Microcyclus have been reported from different lakes (Jones 1978, Schmaljohann et al. 1987, Staley et al. 1987). The edibility of these forms for protozoans remains to be examined and also whether their occurrence is influenced by protozoan grazing pressure.

A trade-off certainly exists for complex bacterial morphotypes between predation avoidance and competition for substrates. The appearance of larger numbers of filaments, aggregates, etc. has been reported mainly from more eutrophic conditions. This suggests that morphologically complex growth forms are inferior competitors under substrate limitation compared to small, single cells (Güde 1989). They probably develop only when predation pressure by phago- 
trophic protists exceeds the competition for substrates. Such situations occur more frequently in eutrophic systems or microenvironments. Moreover, the overall food web structure, e.g. interactions between metazoans and protozoans, is of crucial importance in determining the selection conditions as revealed from the examples in Figs. 2 \& 6 .

Indirect evidence concerning grazing resistance of planktonic bacteria can be derived from in situ experiments in which the protozoan community is released from predation by the removal of metazoans, a technique which is used to estimate the growth rates of planktonic protozoans (e.g. Carrick et al. 1992). The decline of bacteria after the development of phagotrophic protozoans would provide an indication of the availability of the bacterial assemblage to consumers and the proportion of GRB in this situation. Unfortunately, not much attention has been paid to the fate of bacteria in these incubations. In the above mentioned example of an enclosure experiment, where the metazooplankton was manipulated (Fig. 6), the initial bacterial population was obviously edible by protozoans, since bacterial abundance declined by $90 \%$. It remains open to what proportion bacterial assemblages are available for protozoan grazers during other seasons and in other systems.

\section{IMPLICATIONS FOR MICROBIAL FOOD WEBS}

From the evidence outlined above, we conclude that the frequent occurrence of GRB should be expected in natural habitats. If microbial communities play an important role in pelagic systems, as currently believed, then the existence of GRB has potential implications for fundamental ecosystem processes. However, due to the lack of specific investigations, we have at present no concrete ideas about the quantitative importance of GRB in different aquatic environments, the controlling factors and the seasonal dynamics. Our purpose here has been to summarize from the direct and indirect evidence some of the obvious features of GRB, and to outline possible consequences for the structure and function of microbial food webs.

\section{Grazing-resistant bacteria in planktonic food web models}

Despite the obvious lack of more detailed information, we can formulate a preliminary scheme as to how GRB could be included conceptually in models of planktonic food webs:

(1) Grazing resistance has been discussed mainly in response to protozoan grazing which is justified by the fact that nanoflagellates and ciliates have been identified in most case studies as the main bacterivores. It seems to be rather obvious that a mixed bacterial assemblage can shift rapidly in phenotypic and/or genotypic species composition when exposed to heavy grazing by HNF as long as sufficient substrate supply for growth is available. This can be verified by supplying a natural water sample, from which metazooplankton has been removed, with carbon substrates. Normally the appearance of peculiar growth forms (filaments, aggregates, new 'types' of bacteria) can be observed after a mass development of bacterivorous protozoans. Predation and the occurrence of bacteria with different vulnerability may decrease competitive exclusion and hence increase bacterial diversity (Jost et al. 1973).

(2) The appearance of obviously grazing-resistant bacteria (mainly complex morphological forms) has been observed in nature, at least in more nutrient-rich situations. An increased percentage of such morphotypes occurs when protozoan grazing is the dominant selection force. Other types of GRB (e.g. chemically resistant forms), which are not detected by current methodology, might be present as well in these situations.

(3) Predation on protozoans seems to be a key factor for the bacterial community structure. The impact of metazoans on microbial food webs, especially predatory control of protozoans, has received more attention only recently (reviews by Stoecker \& Capuzzo 1990, Arndt 1993, Sanders \& Wickham 1993, Jürgens 1994). Ciliates might be temporarily important as consumers of nanoflagellates as well (Verity 1991b). Metazoans (and larger protozoans) promote in 2 ways the predominance of freely dispersed, single bacterial cells which are vulnerable to grazing by nanoflagellates. First, the suppression of bacterivorous protozoans indirectly reduces grazing pressure on bacteria and thereby enables higher bacterial densities. Second, forms resistant to protozoan grazing (e.g. complex growth forms) can be directly consumed by many metazooplankters. However, it is unlikely that topdown control of protozoans by zooplankton is the only mechanism which enables a relatively constant bacterial standing stock. Zooplankton exhibit pronounced seasonal variability in biomass and species composition, which is also reflected in seasonal changes of protozoan populations. This is not reflected in similar variations of bacterioplankton, which seem to be relatively stable within a given system (see Fig. 3 ).

The inclusion of GRB into a tentative scheme of trophic interactions between bacteria, protozoans and metazoans would help to explain the buffering of bacterial standing stocks. Three different, simplified food web constellations which either promote or suppress 
the development of GRB are shown in Fig. 7. When the abundance of filter-feeding mesozooplankton is high, heterotrophic nanoplankton (HNAN) are predation controlled and the resulting grazing on bacteria is relatively low (Fig. 7A). The major selection force for bacteria is competition for substrates with a predominance of small, freely dispersed single cells which are highly edible for bacterivorous protozoans. The metazoans also have some direct impact on the bacterial community but this depends on the presence of species which are capable of bacterial feeding (e.g. Daphnia). HNAN are often top-down controlled even when mesozooplankton biomass is low because microzooplankton (e.g. oligotrichous ciliates, rotifers) can be the major consumers of HNAN (Fig. 7B). Ciliates can also affect changes in bacterial community structure (Turley et al. 1986) and the proportion of GRB might be increased compared to Fig. 7A. When selectivefeeding mesozooplankton (e.g. cyclopoid copepods) are abundant (Fig. 7C), microzooplankton can be suppressed and the resulting predation on HNAN would be low. In this case, grazing pressure on bacteria by nanoflagellates and small ciliates would promote the change of the bacterial assemblage towards the dominance of protozoan-resistant forms. However, other situations might also result in temporarily low predation on bacterivorous protozoans. For example, the short generation times of bacteria and protozoans may allow them to increase more quickly in response to increases in food resources than metazooplankton.

The outcome of these contrasting food web constellations is that the overall standing stock of bacterial biomass remains relatively unchanged, but the community structure, particularly the proportion of GRB, is altered between the situations depicted in Fig. 7A \& C. The bacterial assemblage would in both cases use the ambient substrate pools and approach the carrying capacity. The bacterivores are cropping only the bacterial production which is edible and do not suppress the bacterial standing stock significantly below the carrying capacity. The 2 simplified scenarios are certainly the extreme cases and intermediate situations are more realistic.

In addition to these examples, which occur in mesoto eutrophic environments, we have to consider the situation of severe nutrient limitation in the bulk phase of oligotrophic waters. Here the bacterial assemblage is characterized by the dominance of ultramicrobacteria, to a large extent cells in a starvation-survival mode. Predation pressure is low because of the low abundance of protozoans (numerical refuge).

\section{Consequences of GRB for carbon flow and nutrient regeneration}

Because of the assumed overall importance of bacterioplankton, the occurrence of GRB should also have significant implications for carbon and nutrient flows in pelagic habitats. Bacteria represent a significant or even predominant fraction of the total planktonic biomass and convert a large proportion of photosynthetically produced carbon into secondary production, providing an important food source for higher trophic levels. Hence, bacteria can be considered as an important trophic link by which otherwise lost detrital energy is channelled back into the planktonic food web (Sherr \& Sherr 1988). At the same time, consumption of bacterial production stimulates primary production and, hence, further increases the trophic energy flow because bacterially bound nutrients are regenerated by grazing activities (Azam et al. 1983)

Obviously, this picture has to be considerably modified if a major part of bacterial biomass is less available to higher trophic levels. This will be the case when GRB dominate the bacterial community, either as non-growing ultramicrobacteria or as large complex growth forms and other types of grazing-resistant cells. In such situations the bacterial biomass must be considered as a refractory 
pool which is characterized by a slow turnover. Besides GRB, there may be a fraction of the bacteria which exhibit high growth, high grazing losses, and high turnover. This view of a rather refractory nature of bacterioplankton as a whole is supported by recent estimates of turnover times of bacterial biomass, which frequently range from several days to weeks (e.g. Fuhrman et al. 1989, Pace et al. 1990, Güde et al. 1991). Thus, the turnover of bacterial biomass can be considered in analogy to the turnover of the DOC pool, which usually constitutes the largest part of organic matter in natural waters. For both DOC and bacteria, the division into a large refractory pool with slow turnover and a small labile and dynamic one seems to be appropriate.

In any case, the existence of GRB necessarily implies a decrease of the overall growth efficiency of bacterioplankton, because the large, slow- or non-growing refractory part is respiring energy. The increased dissipation of energy also leads to a decreased transfer within the system. The resulting shortage of energy will become even stronger when considering the important participation of bacteria in the flow of inorganic nutrients. A large proportion of essentially limiting nutrients is incorporated in bacterial biomass (Vadstein et al. 1988, Jürgens \& Güde 1990). Recycling of these nutrients occurs mainly by bacterivorous protozoans. A buffering of bacterial biomass throughout the growing season by GRB implies an enhanced nutrient storage in the heterotrophic compartments. This results in less recycling and, hence, less supply of limiting nutrients for primary production.

In conclusion, the main implication of GRB seems to be a reduction of the total productivity of pelagic ecosystems, because of decreased energy transfer within the food web and because of decreased regeneration of limiting nutrients. On the other hand, the buffering properties of GRB may also contribute to an enhanced overall stability of a system, which, however, has to be considered more thoroughly by appropriate theoretical models. Obviously the presently available evidence is by far insufficient for a comprehensive understanding of GRB and to judge whether their occurrence might alter the concepts on the role of heterotrophic microorganisms which had been developed a decade ago (Williams 1981, Azam et al. 1983). The development of new techniques which could resolve the composition of natural bacterial communities will certainly yield significant progress and new insights within the near future. The provided data and considerations should stimulate a consideration of the GRB concept more intensively in future studies, in order to achieve a more comprehensive view of the structure and function of bacterioplankton within planktonic food webs.
Acknowledgements. We thank W. R. DeMott, C. Pedrós-Alió, E. \& B. Sherr, M. Landry, H. Arndt and K. O. Rothhaupt for helpful comments on earlier versions of the manuscript and many linguistic improvements.

\section{LITERATURE CITED}

Absolom, D. R. (1988). The role of bacterial hydrophobicity in infection: bacterial adhesion and phagocytic ingestion. Can. J. Microbiol. 34: 287-298

Amblard, C., Sime-Ngando, T., Rachiq, S., Bourdier, G. (1993). Importance of ciliated protozoa in relation to the bacterial and phytoplankton biomass in an oligo-mesotrophic lake, during the spring diatom bloom. Aquat. Sci. 55(1): 1-9

Ammerman, J. W., Fuhrman, J. A., Hagström, A., Azam, F. (1984). Bacterioplankton growth in seawater. I. Growth kinetics and cellular characteristics in seawater culture. Mar. Ecol. Prog. Ser. 18: 9-31

Andersen, P., Sørensen, H. M. (1986). Population dynamics and trophic coupling in pelagic microorganisms in eutrophic coastal waters. Mar. Ecol. Prog. Ser. 33: 99-109

Andersson, A., Larsson, U., Hagström, §. (1986). Sizeselective grazing by a microflagellate on pelagic bacteria. Mar. Ecol. Prog. Ser. 33: 51-57

Arndt, H. (1993). Rotifers as predators on components of the microbial web (bacteria, heterotrophic flagellates, ciliates) - a review. Hydrobiologia 255/256: 231-246

Azam, F., Ammerman, J. W. (1984). Cycling of organic matter by bacterioplankton in pelagic marine ecosystems: microenvironmental considerations. In: Fasham, M. J. R. (ed.) Flows of energy and materials in marine ecosystems. Plenum Press, New York, p. 345-360

Azam, F., Cho, B. C. (1987). Bacterial utilization of organic matter in the sea. In: Fletcher, M., Gray, I. R., Jones, J. G. (eds.) Ecology of microbial communities. Cambridge University Press, Cambridge, p. 261-281

Azam, F., Fenchel, T., Field, J. G., Gray, J. S., Meyer-Reil, L. A., Thingstad, F. (1983). The ecological role of water column microbes in the sea. Mar. Ecol. Prog. Ser. 10: 257-263

Barna, I., Weis, D. S. (1973). The utilization of bacteria as food for Paramecium bursaria. Trans. Am. microsc. Soc. 92: $434-440$

Bell, R., Kuparinen, J. (1984). Assessing phytoplankton and bacterioplankton production during early spring in Lake Erken, Sweden. Appl. environ. Microbiol. 48: 1221-1230

Bianchi, M. (1989). Unusual bloom of star-like prosthecate bacteria and filaments as a consequence of grazing pressure. Microb. Ecol. 17: 137-141

Biddanda, B. A. (1985). Microbial synthesis of macroparticulate matter. Mar. Ecol. Prog. Ser. 20: 241-251

Biddanda, B. A., Pomeroy, L. R. (1988). Microbial aggregation and degradation of phytoplankton-derived detritus in seawater. I. Microbial succession. Mar. Ecol. Prog. Ser. 42: $79-88$

Billen, G., Fontigny, A. (1987). Dynamics of a Phaeocystisdominated spring bloom in Belgian coastal waters. Mar. Ecol. Prog. Ser. 37: 249-257

Billen, G., Servais, P., Becquevort, S. (1990). Dynamics of bacterioplankton in oligotrophic and eutrophic aquatic environments: bottom-up or top-down control? Hydrobiologia 207: $37-42$

Bird, D. F., Kalff, J. (1984). Empirical relationships between bacterial abundance and chlorophyll concentration in fresh and marine waters. Can. J. Fish. Aquat. Sci. 41: 1015-1023 
Børsheim, K. Y., Andersen, S., Johnsen, G. H., Kambestad, E. Ø., Norland, S. (1988). Primary and bacterial production compared to growth and food requirements of Daphnia longispina in Lake Kvernavatnet, west Norway. J. Plankton Res. 10: 921-939

Brendelberger, H. (1991). Filter mesh size of cladocerans predicts retention efficiency for bacteria. Limnol. Oceanogr. 36: $884-894$

Brettar, I., Höfle, M. (1992). Influence of ecosystematic factors on survival of Escherichia coli after large-scale release into lake water mesocosms. Appl. environ. Microbiol. 58: 2201-2210

Brooks, J. L., Dodson, S. I. (1965). Predation, body size, and composition of plankton. Science 150: 28-35

Caron, D. A. (1987). Grazing of attached bacteria by heterotrophic microflagellates. Microb. Ecol. 13: 203

Caron, D. A., Davis, P. G., Madin, L. P., Sieburth, J. M. (1982). Heterotrophic bacteria and bacterivorous protozoa in oceanic macroaggregates. Science 218: 795-797

Caron, D. A., Goldman, J. C. (1990). Protozoan nutrient regeneration. In: Capriulo, G. M. (ed.) Ecology of marine protozoa. Oxford University Press, New York, p. 283-306

Caron, D. A., Goldman, J. C., Dennett, M. R. (1988). Experimental demonstration of the roles of bacteria and bacterivorous protozoa in plankton nutrient cycles. Hydrobiologia 159: 27-40

Carrick, H. J., Fahnenstiel, G. L., Taylor, W. D. (1992). Growth and production of planktonic protozoa in Lake Michigan: in situ versus in vitro comparisons and importance to food web dynamics. Limnol. Oceanogr. 37: 1221-1235

Cho, B. C., Azam, F. (1988). Major role of bacteria in biogeochemical fluxes in the ocean's interior. Nature. 332 441-443

Chrzanowski, T. H., Simek, K. (1990). Prey-size selection by freshwater flagellated protozoa. Limnol. Oceanogr. 35: 1429-1436

Cole, J. J., Findlay, S., Pace, M. L. (1988). Bacterial production in fresh and saltwater ecosystems: a cross-system overview. Mar. Ecol. Prog. Ser. 43: 1-10

Cole, J. J., Pace, M. L., Caraco, N. F., Steinhart, G. S. (1993). Bacterial biomass and cell size distributions in lakes: more and larger cells in anoxic waters. Limnol. Oceanogr. 38: $1627-1632$

Coveney, M. F., Cronberg, G., Enell, M., Larsson, K., Olofsson, L. (1977). Phytoplankton, zooplankton and bacteria standing crop and production relationships in a eutrophic lake. Oikos 29: 5-21

Cunningham, R. K., Söderström, T. O., Gillman, C. F., Van Oss, C. J. (1975). Phagocytosis as a surface phenomenon. V. Contact angles and phagocytosis of rough and smooth strains of Salmonella typhirum, and the influence of specific antiserum. Immun. Commun. 4: 429-442

Curds, C. R. (1982). The ecology and role of protozoa in aerobic sewage treatment processes. A. Rev. Microbiol. 36: 27-46

Curds, C. R., Vandyke, J. M. (1966). The feeding habits and growth rates of some freshwater ciliates found in activated sludge plants. J. appl. Ecol. 3: 127-137

Decho, A. W. (1990). Microbial exopolymer secretions in oceanic environments: their role(s) in food webs and marine processes. Oceanogr. mar. Biol. A. Rev. 28: 73-153

Dubowsky, N. (1974). Selectivity of ingestion and digestion in the chrysomonad flagellate Ochromonas malhamensis. J. Protozool. 21: 295-298

Ducklow, H. W. (1983). Production and fate of bacteria in the oceans. BioSci. 33: 494-501

Ducklow, H. W., Kirchman, D. L., Quinby, H. L., Carlson, C. A., Dam, H. G. (1993). Stocks and dynamics of bacterio- plankton carbon during the spring bloom in the eastern North Atlantic Ocean. Deep Sea Res. 40: 245-263

Edwards, P. J., Gillman, M. P. (1987). Herbivores and plant succession. In: Gray, A. J., Crawley, M. J., Edwards, P. J. (eds.) Colonization, succession and stability, 26th Symposium of the British Ecological Society. Blackwell. Oxford, p. 295-314

Ellwood, D. C., Tempest, D. W. (1972). Effects of environment on bacterial wall content and composition. Adv. microb. Phys. 7: 83-117

England, L. S., Lee, H., Trevors, J. T. (1993). Bacterial survival in soil: effect of clays and protozoa. Soil Biol. Biochem. 25: $525-531$

Epstein, S. S., Shiaris, M. P. (1992). Size-selective grazing of coastal bacterioplankton by natural assemblages of pigmented flagellates, colorless flagellates, and ciliates. Microb. Ecol. 23: 211-225

Fenchel, T. (1980). Suspension feeding in ciliated protozoa: functional response and particle size selection. Microb. Ecol. 6: 1-11

Fenchel, T. (1982a). Ecology of heterotrophic microflagellates. I. Some important forms and their functional morphology. Mar. Ecol. Prog. Ser. 8: 211-223

Fenchel, T. (1982b). Ecology of heterotrophic microflagellates. Il. Bioenergetics and growth. Mar. Ecol. Prog. Ser. 8 : 225-231

Fenchel, T. (1984). Suspended marine bacteria as a food source. In: Fasham, M. J. (ed.) Flows of energy and materials in marine ecosystems. Plenum Press, New York, p. 301-315

Fenchel, T., Finlay, B. J. (1991). The biology of free-living anaerobic ciliates. Eur. J. Protistol. 26: 201-215

Flood, P. R., Deibel, D., Morris, C. C. (1992). Filtration of colloidal melanin from sea water by planktonic tunicates. Nature 355: 630-632

Fuhrman, J. A., Sleeter, T. D., Carlson, C. A., Proctor, L. M. (1989). Dominance of bacterial biomass in the Sargasso Sea and its ecological implications. Mar. Ecol. Prog. Ser. 57: $207-217$

Fukami, K., Simidu, U., Taga, N. (1985). Microbial decomposition of phyto- and zooplankton in seawater. II. Changes in bacterial community. Mar. Ecol. Prog. Ser. 21: 7-13

Gasol, J. M., Vaqué, D. (1993). Lack of coupling between heterotrophic nanoflagellates and bacteria: a general phenomenon across aquatic systems? Limnol. Oceanogr. 38: $657-665$

Goldman, J. C. (1984). Conceptual role for microaggregates in pelagic waters. Bull. mar. Sci. 35: 462-476

González, J. M., Iriberri, J., Egea, L., Barcina, I. (1990). Differential rates of digestion of bacteria by freshwater and marine phagotrophic protozoa. Appl. environ. Microbiol. 56: $1851-1857$

González, J. M., Sherr, E. B., Sherr, B. F. (1990). Size-selective grazing on bacteria by natural assemblages of estuarine flagellates and ciliates. Appl. environ. Microbiol. 56: 583-589

González, J. M., Sherr, E. B., Sherr, B. F. (1993). Differential feeding by marine flagellates on growing versus starving, and on motile versus nonmotile, bacterial prey. Mar. Ecol. Prog. Ser, 102: 257-267

González, J. M. Suttle, C. A. (1993). Grazing by marine nanoflagellates on viruses and virus-sized particles: ingestion and digestion. Mar. Ecol. Prog. Ser. 94: 1-10

Goulder, R. (1976). Relationships between suspended solids and standing crops and activities of bacteria in an estuary during a neap-spring-neap tidal cycle. Oecologia 24 : $83-90$ 
Güde, H. (1979). Grazing by protozoa as selection factor for activated sludge bacteria. Microb. Ecol. 5: 225-237

Güde, H. (1982). Interactions between floc-forming and nonfloc-forming bacterial populations from activated sludge. Curr. Microbiol. 7: 347-350

Güde, H. (1986). Loss processes influencing growth of bacterial populations in Lake Constance. J. Plankton Res. 8: 795-810

Güde, H. (1988). Direct and indirect influences of crustacean zooplankton on bacterioplankton of Lake Constance. Hydrobiologia 159: 63-73

Güde, H. (1989). The role of grazing on bacteria in plankton succession. In: Sommer, U. (ed.) Plankton ecology, Succession in plankton communities. Springer, Berlin, p. 337-364

Güde, H. (1993). Uniformity and diversity in the phenotypic structure of heterotrophic bacterioplankton. In: Guerrero, R., Pedrós-Alió, C. (eds.) Trends in microbial ecology. Spanish Society of Microbiology, Barcelona, p. 359-362

Güde, H., Haibel, B., Müller, H. (1985). Development of planktonic bacterial populations in a water column of Lake Constance (Bodensee-Obersee). Arch. Hydrobiol. 105: $59-77$

Güde, H., Jürgens, K., Parth, G., Walser, R. (1991). Indications for low net productivity of pelagic bacterioplankton. Kieler Meeresforsch., Sonderh. 8: 309-316

Hadas, O., Pinkas, R., Albert-Diez, C., Bloem, J., Cappenberg, T., Berman, T. (1990). The effect of detrital addition on the development of nanoflagellates and bacteria in Lake Kinneret. J. Plankton Res. 12: 185-199

Hessen, D. O. (1985). The relation between bacterial carbon and dissolved humic compounds in oligotrophic lakes. FEMS Microbiol. Ecol. 31: 215-223

Hoch, M. P., Kirchman, D. L. (1993). Seasonal and interannual variability in bacterial production and biomass in a temperate estuary. Mar. Ecol. Prog. Ser. 98: 283-295

Holen, D. A., Boraas, M. E. (1991). The feeding behavior of Spumella sp. as a function of particle size: implications for bacterial size in pelagic systems. Hydrobiologia 220: 73-88

Holmquist, L., Kjelleberg, S. (1993). Changes in viability, respiratory activity and morphology of the marine Vibrio sp. strain S14 during starvation of individual nutrients and subsequent recovery. FEMS Microbiol. Ecol. 12: 215-224

Inamori, Y., Kuniyasu, Y., Sudo, R., Koga, M. (1991). Control of the growth of filamentous microorganisms using predacious ciliated protozoa. Water Sci. Tech. 23: 963-971

Johansson, J.-A. (1983). Seasonal development of bacterioplankton in two forest lakes in central Sweden. Hydrobiologia 101: 71-88

Jonas, R. B., Tuttle, J. H. (1990). Bacterioplankton and organic carbon dynamics in the lower mesohaline Chesapeake Bay. Appl. environ. Microbiol. 56: 747-757

Jones, J. G. (1978). The distribution of some freshwater planktonic bacteria in two stratified eutrophic lakes. Freshwat. Biol. 8: 127-140

Jost, J. L., Drake, J. F., Tsuchiya, H. M., Fredrickson, A. G (1973). Microbial food chains and food webs. J. theor. Biol 41: 461-484

Jürgens, K. (1992). Is there plenty of food for bacterivorous flagellates in eutrophic waters? Arch. Hydrobiol. Beih. Ergebn. Limnol. 37: 195-205

Jürgens, K. (1994). Impact of Daphnia on planktonic microbial food webs - a review. Mar. Microb. Food Webs 8 (in press)

Jürgens, K., Arndt, H., Rothhaupt, K. O. (1994). Zooplanktonmediated changes of bacterial community structure. Microb. Ecol. 27: 27-42
Jürgens, K., Güde, H. (1990). Incorporation and release of phosphorus by planktonic bacteria and phagotrophic flagellates. Mar. Ecol. Prog. Ser. 59: 271-284

Jürgens, K., Güde, H. (1991). Seasonal changes in the grazing impact of phagotrophic flagellates on bacteria in Lake Constance. Mar. Microb. Food Webs 5: 27-37

Jürgens, K., Stolpe, G. (in press). Seasonal dynamics of crustacean zooplankton, heterotrophic nanoflagellates and bacteria in a shallow, eutrophic lake. Freshwat. Biol

King, C. H., Sanders, R. W., Shotts, E. B., Porter, K. G. (1991). Differential survival of bacteria ingested by zooplankton from a stratified eutrophic lake. Limnol. Oceanogr. 36: $829-845$

King, C. H., Shotts, E. B., Wooley, R. E., Porter, K. G. (1988). Survival of coliforms and bacterial pathogens within protozoa during chlorination. Appl. environ. Microbiol. 54: 3023-3033

King, K. R., Hollibaugh, J. T., Azam, F. (1980). Predator-prey interactions between the larvacean Oikopleura dioica and bacterioplankton in enclosed water columns. Mar. Biol. 56: $49-57$

Kirchman, D. L. (1983). The production of bacteria attached to particles suspended in a freshwater pond. Limnol. Oceanogr. 28: 858-872

Kirchman, D. L., Keil, R. G., Simon, M., Welschmeyer, N. A. (1993). Biomass and production of heterotrophic bacterioplankton in the oceanic subarctic Pacific. Deep Sea Res. 40: $967-988$

Kivi, K., Kaitala, S., Kuosa, H., Kuparinen, J., Leskinen, E., Lignell, R., Marcussen, B., Tamminen, T. (1993). Nutrient limitation and grazing control of the Baltic plankton community during annual succession. Limnol. Oceanogr. 38: 893-905

Kjelleberg, S. (1993). Starvation in bacteria. Plenum Press, New York

Kjelleberg, S., Hermansson, M. (1984). Starvation-induced effects on bacterial surface characteristics. Appl. environ. Microbiol. 48: 497-503

Krambeck, C. (1988). Control of bacterioplankton structures by grazing and nutrient supply during the decline of an algal bloom. Verh. int. Verein. Limnol. 23: 496-502

Krambeck, C., Krambeck, H.-J., Schröder D. (1990). Sizing bacterioplankton: a juxtaposition of bias due to shrinkage, halos, subjectivity in image interpretation and asymmetric distributions. Binary $2: 5-14$

Kuno, E. (1987). Principles of predator-prey interaction in theoretical, experimental, and natural population systems. Adv. Ecol. Res. 16: 249-337

Kuuppo-Leinikki, P. (1990). Protozoan grazing on planktonic bacteria and its impact on bacterial population. Mar. Ecol. Prog. Ser. 63: 227-238

Laanbroek, H. J., Verplanke, J. C., Visscher, P. R. M. de, Vuyst, R. de (1985). Distribution of phyto- and bacterioplankton growth and biomass parameters, dissolved inorganic nutrients and free amino acids during a spring bloom in the Oostershelde basin, The Netherlands. Mar. Ecol. Prog. Ser. 25: 1-11

Lampert, W. (1981). Inhibitory and toxic effects of blue-green algae on Daphnia. Int. Revue ges. Hydrobiol. 66: 285-298

Lampert, W., Fleckner, W., Rai, H., Taylor, B. E. (1986). Phytoplankton control by grazing zooplankton: a study on the spring clear-water phase. Limnol. Oceanogr. 31: 478-490

Landry, M. R., Lehner-Fournier, J. M., Sundstrom, J. A., Fagrness, V. L., Selph, K. E. (1991). Discrimination between living and heat-killed prey by a marine zooflagellate, Paraphysomonas vestita (Stokes). J. exp. mar. Biol. Ecol. 146: 139-151 
Larsson, U., Hagström, ^. (1982). Fractionated phytoplankton primary production, exudate release and bacterial production in a baltic eutrophication gradient. Mar. Biol. 67: $57-70$

Lauffenburger, D. A. (1991). Quantitative studies of bacterial chemotaxis and microbial population dynamics. Microb. Ecol. 22: 175-185

Lawrence, S. G., Ahmad, A., Azam, F. (1993). Fate of particlebound bacteria ingested by Calanus pacificus. Mar. Ecol. Prog. Ser. 97: 299-307

Lean, D. R. S., Abbott, A. P., Charlton, M. N., Rao, S. S. (1983). Seasonal phosphate demand for Lake Erie plankton. J. Great Lakes Res. 9: 83-91

Leibold, M. A. (1989). Resource edibility and the effects of predators and productivity on the outcome of trophic interactions. Am. Nat. 134: 922-949

Lock, M. A., Wallace, R. R., Costerton, J. W., Ventullo, R. M., Charlton, S. E. (1984). River epilithon: toward a structuralfunctional model. Oikos 42: 10-22

Lock, R., Öhman, L., Dahlgren, C. (1987). Phagocytic recognition mechanisms in human granulocytes and Acanthamoeba castellanii using type 1 fimbriated Escherichia coli as phagocytic prey. FEMS Microbiol. Lett. 44: 135-140

Lucas, M. I. (1986). Decomposition in pelagic marine ecosystems. J. Limnol. Soc. sth. Afr. 12: 99-122

Ly, T. M. C., Müller, H. E. (1990). Interactions of Listeria monocytogenes, Listeria seeligeri, and Listeria innocua with protozoans. J. gen. appl. Microbiol. 36: 143-150

Malone, T. C., Ducklow, H. W., Peele, E. R., Pike, S. E. (1991), Picoplankton carbon flux in Chesapeake Bay. Mar. Ecol. Prog. Ser. 78: 11-22

Malone, T. C., Kemp, W. M., Ducklow, H. W., Boynton, W. R., Tuttle, J. H., Jonas, R. B. (1986). Lateral variation in the production and fate of phytoplankton in a partially stratified estuary. Mar. Ecol. Prog. Ser. 32: 149-160

Marchant, H. J., Scott, F. J. (1993). Uptake of sub-micrometre particles and dissolved organic material by Antarctic choanoflagellates. Mar. Ecol. Prog. Ser. 92: 59-64

Marodi, L., Burjan, P., Rozgony, F. (1990). Opsonic requirements and surface hydrophobicity of novobiocin-resistant, coagulase-negative staphylococci. J. med. Microbiol. 32: 19-24

McGinnes, S., Johnson, D. B. (1992). Grazing of acidophilic bacteria by a flagellated protozoan. Microb. Ecol. 23: 75-86

McManus, G. B., Fuhrman, J. A. (1988). Clearance of bacteria-sized particles by natural populations of nanoplankton in the Chesapeake Bay outflow plume. Mar. Ecol. Prog. Ser. 42: 199-206

Meier, B. G. (1991). Untersuchungen zur 'Microbial Loop' im Plußsee. Ph.D. thesis, University of Kiel

Mitchell, G. C., Baker, J. H., Sleigh, M. A. (1988). Feeding of a freshwater flagellate, Bodo saltans, on diverse bacteria. J. Protozool. 35: 219-222

Monger, B. C., Landry, M. R. (1990). Direct-interception feeding by marine zooflagellates: the importance of surface and hydrodynamic forces. Mar. Ecol. Prog. Ser. 65: 123-140

Monger, B. C., Landry, M. R. (1991). Prey-size dependency of grazing by free-living marine flagellates. Mar. Ecol. Prog. Ser. 74: 239-248

Monger, B. C., Landry, M. R. (1992). Size-selective grazing by heterotrophic nanoflagellates: an analysis using livestained bacteria and dual-beam flow cytometry. Arch. Hydrobiol. Beih. Ergebn. Limnol. 37: 173-185

Morita, R. Y. (1982). Starvation-survival of heterotrophs in the marine environment. Adv. Microb. Ecol. 6: 171-198

Murdoch, W. W., Oaten, A. (1975). Predation and population stability. Adv. Ecol. Res. 9: 1-131
Nagata, T. (1987). Production rate of planktonic bacteria in the north basin of Lake Biwa, Japan. Appl. environ. Microbiol. 53: 2872-2882

Newell, R. C., Lucas, M. I., Linley, E. A. S. (1981). Rate of degradation and efficiency of conversion of phytoplankton debris by marine microorganisms. Mar. Ecol. Prog. Ser. 6: 123-136

Oksanen, L., Fretwell, S. D., Arruda, J., Niemelä, P. (1981). Exploitation ecosystems in gradients of primary productivity. Am. Nat. 118: 240-261

Pace, M. L. (1988). Bacterial mortality and the fate of bacterial production. Hydrobiologia 9: 41-49

Pace, M. L., Funke, E. (1991). Regulation of planktonic microbial communities by nutrients and herbivores. Ecology. 72: 904-914

Pace, M. L., McManus, G. B., Findlay, S. E. G. (1990). Planktonic community structure determines the fate of bacterial production in a temperate lake. Limnol. Oceanogr. 35: 795-808

Painting, S. J., Lucas, M. I., Muir, D. G. (1989). Fluctuations in heterotrophic bacterial community structure, activity and production in response to development and decay of phytoplankton in a microcosm. Mar. Ecol. Prog. Ser. 53: 129-141

Patel, G. B., Roth, L. A., Sprott, G. D. (1979). Factors influencing filament length of Methanospirillum hungatii. J. gen. Microbiol. 112: 411-415

Pedrós-Alió, C. (1993). Diversity of bacterioplankton. Trends Ecol. Evolut. 8: 86-90

Pedrós-Alió C., Brock, T. D. (1983a). The importance of attachment to particles for planktonic bacteria. Arch. Hydrobiol. 98: $354-379$

Pedrós-Alió, C., Brock, T. D. (1983b). The impact of zooplankton feeding on the epilimnetic bacteria of a eutrophic lake. Freshwat. Biol. 13: 227-239

Pedrós-Alió, C., Guerrero, R. (1993). Microbial ecology in Lake Cisó. Adv. Microb. Ecol. 13: 155-209

Porter, K. G. (1973). Selective grazing and differential digestion of algae by zooplankton. Nature 244: 179-180

Porter, K. G. (1977). The plant-animal interface in freshwater ecosystems. Am. Scient. 65: 159-170

Porter, K. G., Feig, Y. S., Vetter, E. F. (1983). Morphology, flow regimes, and filtering rates of Daphnia, Ceriodaphnia, and Bosmina fed natural bacteria. Oecologia 58: 153-163

Rao, S. S., Kwiatkowski, R. E., Jurkovic, A. A. (1979). Distribution of bacteria and chlorophyll $a$ at a nearshore station in Lake Ontario. Hydrobiologia 66: 33-39

Rault, P. L., Sohier, L. P., Rivier, A. M., Daumas, R. A. (1988). Dark bacterial-protozoan culture: acidification, nitrite accumulation, and protozoan inhibition in absence of phytoplankton. J. exp. mar. Biol. Ecol. 116: 273-291

Riemann, B. (1983). Biomass and production of phyto- and bacterio-plankton in eutrophic Lake Tystrup, Denmark. Freshwat. Biol. 13: 389-398

Riemann, B. (1985). Potential importance of fish predation and zooplankton grazing on natural populations of freshwater bacteria. Appl. environ. Microbiol. 50: 187-193

Riemann, B., Søndergaard, M., Schierup, H.-H., Bosselmann, S., Christensen, G., Hansen, J., Nielsen, B. (1982). Carbon metabolism during spring diatom bloom in the eutrophic Lake Mossø. Int. Revue ges. Hydrobiol. 67: 145-185

Robertson, M. L., Mills, A. L., Zieman, J. C. (1982). Microbial synthesis of detritus-like particulates from dissolved organic carbon released by tropical seagrasses. Mar. Ecol. Prog. Ser. 7: 279-285

Roszak, D. B., Colwell, R. R. (1987). Survival strategies of bacteria in the natural environment. Microb. Rev. 51: $365-379$ 
Sanders, R. W., Caron, D. A., Berninger, U.-G. (1992). Relationships between bacteria and heterotrophic nanoplankton in marine and fresh waters: an inter-ecosystem comparison. Mar. Ecol. Prog. Ser. 86: 1-14

Sanders, R. W., Porter, K. G., Bennett, S. L., DeBiase, A. E. (1989). Seasonal patterns of bacterivory by flagellates, ciliates, rotifers, and cladocerans in a freshwater planktonic community. Limnol. Oceanogr. 34: 673-687

Sanders, R. W., Wickham, S. A. (1993). Planktonic protozoa and metazoa: predation, food quality and population control. Mar. Microb. Food Webs 7: 197-223

Scavia, D., Laird, G. A. (1987). Bacterioplankton in Lake Michigan: dynamics, controls, and significance to carbon flux. Limnol. Oceanogr. 32: 1017-1033

Schmaljohann, R., Pollingher, U., Berman, T. (1987). Natural populations of bacteria in Lake Kinneret: observations with scanning electron and epifluorescence microscopy. Microb. Ecol. 13: 1-12

Schoenberg, S. A., Maccubin, A. E. (1985). Relative feeding rates on free and particle-bound bacteria by freshwater macrozooplankton. Limnol. Oceanogr. 30: 1084-1090

Schut, F., De Vries, E. J., Gottschal, J. C., Robertson, B. R., Harder, W., Prins, R. A., Button, D. K. (1993). Isolation of typical marine bacteria by dilution culture: growth, maintenance, and characteristics of isolates under laboratory conditions. Appl. environ. Microbiol. 59: 2150-2160

Sherr, B. F., Sherr, E. B. (1984). Role of heterotrophic protozoa in carbon and energy flow in aquatic ecosystems. In: Klug, M. J., Reddy, C. A. (eds.) Current perspectives in microbial ecology. American Society for Microbiology, Washington, DC, p. 412-423

Sherr, B. F., Sherr, E. B., Berman, T. (1983). Grazing, growth, and ammonium excretion rates of a heterotrophic microflagellate fed with four species of bacteria. Appl, environ, Microbiol. 45: 1196-1201

Sherr, B. F., Sherr, E. B., McDaniel, J. (1992). Effect of protistan grazing on the frequency of dividing cells in bacterioplankton assemblages. Appl. environ. Microbiol. 58: 2381-2385

Sherr, E. B. (1988). Direct use of high molecular weight polysaccaride by heterotrophic flagellates. Nature 335 : $1225-1227$

Sherr, E. B., Sherr, B. F. (1988). Role of microbes in pelagic food webs: a revised concept. Limnol. Oceanogr. 33: $1225-1227$

Shikano, S., Luckinbill, L. S., Kurihara, Y. (1990). Changes of traits in a bacterial population associated with protozoal predation. Microb. Ecol. 20: 75-84

Shimeta, J., Jumars, P. A. (1991). Physical mechanisms and rates of particle capture by suspension-feeders. Oceanogr. mar. Biol. A. Rev, 29: 191-257

Sibbald, M. J., Albright, L. J. (1988). Aggregated and free bacteria as food sources for heterotrophic microflagellates. Appl. environ. Microbiol. 54: 613-616

Sieburth, J. M. (1984). Protozoan bacterivory in pelagic marine waters. In: Hobbie, J. E., Williams, P. J. leB. (eds.) Heterotrophic activity in the sea. Plenum Press, New York, p. $405-444$

Sih, A. (1987). Predators and prey lifestyles: an evolutionary and ecological overview. In: Kerfoot, W. C., Sih, A. (eds.) Predation: direct and indirect impacts on aquatic communities. University Press of New England, Hanover, p. 203-224

Sime-Ngando, T., Bourdier, G., Amblard, C., Pinel-Alloul, B. (1991). Short-term variations in specific biovolumes of different bacterial forms in aquatic ecosystems. Microb. Ecol. 21: 211-226
Simek, K., Chrzanowski, T. H. (1992). Direct and indirect evidence of size-selective grazing on pelagic bacteria by freshwater nanoflagellates. Appl. environ. Microbiol. 58: $3715-3720$

Śimek, K., Macek, M., Seda, J., Vyhnálek, V. (1990). Possible food chain relationships between bacterioplankton, protozooplankton, and cladocerans in a reservoir. Int. Rev. ges. Hydrobiol. 75: 583-596

Simon, M., Cho, B. C., Azam, F. (1992). Significance of bacterial biomass in lakes and the ocean: comparison to phytoplankton biomass and biogeochemical implications. Mar. Ecol. Prog. Ser. 86: 103-110

Singh, B. N. (1941). Selectivity in bacterial food by soil amoebae in pure mixed culture and in sterilized soil. Ann. appl. Biol. 33: 112-119

Staley, J. T., Konopka, A. E., Dalmasso, J. P. (1987). Spatial and temporal distribution of Caulobacter spp. in two mesotrophic lakes. FEMS Microbiol. Ecol. 45: 1-6

Sterner, R. W. (1989). The role of grazers in phytoplankton succession. In: Sommer, U. (ed.) Plankton ecology. Succession in plankton communities. Springer, Berlin, p. 107-169

Stevenson, L. H. (1978). A case for bacterial dormancy in aquatic systems. Microb. Ecol. 4: 127-133

Stoecker, D. K., Capuzzo, J. M. (1990). Predation on protozoa: its importance to zooplankton. J. Plankton Res. 12: 891-908

Taylor, W. D., Berger, J. (1976). Growth responses of cohabiting ciliate protozoa to various prey bacteria. Can. J. Zool. 54: 1111-1114

Tempest, D. W., Neijssel, O. M. (1978). Eco-physiological aspects of microbial growth in aerobic nutrient limited environments. Adv. Microb. Ecol. 2: 105-153

Thom, S., Warhurst, D., Drasar, B. S. (1992). Association of Vibrio cholerae with fresh water amoebae. J. med. Microbiol. 36: 303-306

Torella, F., Morita, R. Y. (1981). Microcultural study of bacterial size changes and microcolony and ultramicrocolony formation by heterotrophic bacteria in seawater. Appl. environ. Microbiol. 41: 518-527

Tranvik, L. J., Sherr, E. B., Sherr, B. F. (1993). Uptake and utilization of 'colloidal DOM' by heterotrophic flagellates in seawater. Mar. Ecol. Prog. Ser. 92: 301-309

Turley, C. M., Newell, R. C., Robins, D. B. (1986). Survival strategies of two small marine ciliates and their role in regulating bacterial community structure under experimental conditions. Mar. Ecol. Prog. Ser. 33: 59-70

Vadstein, O., Jensen, A., Olsen, Y., Reinertsen, H. (1988). Growth and phosphorus status of limnetic phytoplankton and bacteria. Limnol. Oceanogr. 33: 489-503

van Boekel, W. H. M., Hansen, F. C., Riegman, R., Bak, R. P. M. (1992). Lysis-induced decline of a Phaeocystis spring bloom and coupling with the microbial foodweb. Mar. Ecol. Prog. Ser. 81: 269-276

van Oss, C. J. (1978). Phagocytosis as a surface phenomenon. A. Rev. Microbiol. 32: 19-39

van Wambeke, F., Bianchi, M. A. (1985). Bacterial biomass production and ammonium regeneration in Mediterranean sea water supplemented with amino acids. 2 . Nitrogen flux through heterotrophic microplankton food chain. Mar. Ecol. Prog. Ser. 23: 117-128

Vargas, R., Hattori, T. (1986). Protozoan predation of bacterial cells in soil aggregates. FEMS Microbiol. Ecol. 38: 233-242

Velimirov, B., Walenta-Simon, M. (1992). Seasonal changes in specific growth rates, production and biomass of a bacterial community in the water column above a Mediterranean seagrass system. Mar. Ecol. Prog. Ser. 80: 237-248 
Verity, P. G. (1991a). Feeding in planktonic protozoans: evidence for non-random acquisition of prey. J. Protozool. 38: $69-76$

Verity, P. G. (1991b). Measurement and simulation of prey uptake by marine planktonic ciliates fed plastidic and aplastidic nanoplankton. Limnol. Oceanogr. 36: $729-750$

Weisse, T. (1991). The annual cycle of heterotrophic freshwater nanoflagellates: role of bottom-up versus top-down control. J. Plankton Res. 13: 167-185

Wikner, J., Hagström, §. (1988). Evidence for a tightly coupled nanoplanktonic predator-prey link regulating the bacterivores in the marine environment. Mar. Ecol. Prog. Ser. 50: $137-145$

This review was submitted to the editor
Wikner, J., Hagström, А. (1991). Annual study of bacterioplankton community dynamics. Limnol. Oceanogr. 36: $1313-1324$

Williams, P. J. leB. (1981). Incorporation of microheterotrophic processes into the classical paradigm of the planktonic food-web. Kieler Meeresforsch. 5: 1-28

Wright, R. T. (1988). A model for short-term control of the bacterioplankton by substrate and grazing. Hydrobiologia 159: $111-117$

Wright, R. T., Coffin, R. B. (1984). Factors affecting bacterioplankton density and productivity in salt marsh estuaries. In: Klug, M. J., Reddy, C. A. (eds.) Current perspectives in microbial ecology. American Society for Microbiology, Washington, DC, p. 485-494

Manuscript first received: February 21, 1994

Revised version accepted: June 27, 1994 